\title{
LATE QUATERNARY HISTORY OF LOW- AND MID-ELEVATION VEGETATION IN THE WHITE MOUNTAINS OF NEW HAMPSHIRE ${ }^{1}$
}

\author{
Ray W. Spear, ${ }^{2}$ Margaret B. Davis, and Linda C. K. Shane ${ }^{3}$ \\ Department of Ecology, Evolution and Behavior, University of Minnesota, Minneapolis, Minnesota 55455 USA
}

\begin{abstract}
Pollen and plant macrofossil analyses of sediments from an altitudinal series of lakes in the White Mountains of New Hampshire, USA were used to reconstruct the history of vegetation on the mountain slopes and to identify the factors responsible for vegetation change. Six sites, Mirror Lake $(213 \mathrm{~m})$, Lost Pond $(625 \mathrm{~m})$, Little East Pond (793 m), Lonesome Lake $(831 \mathrm{~m})$, Carter Notch Pond $(1004 \mathrm{~m})$, and Lake of the Clouds $(1538 \mathrm{~m})$, provide paleoecological records of changes in the altitudinal limits of species, the species abundances within communities, and the vegetation zones. These are supplemented by previously published data from three high-elevation sites (Spear 1989). Although past plant communities were different from modern ones, differentiation of vegetation along the slopes has always existed. At low elevations the sequence of vegetation change was: $13700-11500$ yr BP, tundra; $11500-9000$ yr BP, transitional mixed-conifer woodlands of first spruce (Picea) and then fir (Abies balsamea), larch (Larix laricina), poplar (Populus), and paper birch (Betula papyrifera); 9000-7000 yr BP, forests dominated by pine (Pinus) and oak (Quercus); 7000 yr BP-present, mixed-hardwood forests.

No late-glacial paleoecological records exist at mid-elevation sites (700-1200 m). The steep slopes at these elevations stabilized by $10000 \mathrm{yr}$ BP and an early woodland of spruce was replaced by fir, larch, and paper birch. The altitudinal limits of both white pine (Pinus strobus) and hemlock (Tsuga canadensis) expanded to mid-elevations during the midHolocene, suggesting greater warmth $6000-4000 \mathrm{yr}$ BP. The modern spruce/fir forests of mid-elevations became established $2000 \mathrm{yr}$ ago as spruce expanded at all elevations, suggesting cooler, moister climate similar to today.

A tree line dominated by balsam fir and black spruce (Picea mariana) was established at its modern position $10000 \mathrm{yr}$ ago and has varied little since then, although it appears to have been slightly higher than now during the early Holocene.

Changes in the vegetation at low and mid-elevations have not been synchronous with those at tree line and result from a more complex set of environmental factors and climatic variables acting on several different species. At low and mid-elevations disturbance by wind and frost action was important during the late-glacial. Disturbance by fire was important during the period of spruce woodland and later in the early Holocene pine and oak forests. From $7000 \mathrm{yr}$ BP to the present the primary factor disturbing New Hampshire forest was again probably wind, especially from 7000 to $4000 \mathrm{yr}$ BP when higher temperatures than present may have been associated with increased frequency and intensity of thunderstorms and tropical hurricanes. The vegetation history reveals that different lapse rates have occurred along the mountain slopes. This provides evidence that the source of air masses reaching the White Mountains has varied. The boundary between alpine tundra and subalpine fir forest (tree line) most likely has always been governed by temperature (summer insolation) and wind. The montane plant communities result from individual species response rather than community response to the numerous climatic forces that have affected the mountains over the past $14000 \mathrm{yr}$.
\end{abstract}

Key words: community change; forest history; New Hampshire mountains; paleoecology; palynology; plant macrofossils; vegetation zonation.

\section{INTRODUCTION}

Paleoecological studies in mountainous regions are important because areas of high relief should have sensitive records of vegetation and climatic change. In

\footnotetext{
${ }^{1}$ Manuscript received 8 August 1989; revised 28 November 1992; accepted 3 March 1993.

${ }^{2}$ Present address: Biology Department, State University College, Geneseo, New York 14454 USA.

${ }^{3}$ Present address: Limnological Research Center, University of Minnesota, Minneapolis, Minnesota 55455 USA.
}

contrast to flat-lying topography where large distances between vegetation and climate zones may lead to time lags in biotic adjustment, environmental zones in mountains are smaller in area and contain steeper gradients.

The $1300 \mathrm{~m}$ of relief in the White Mountains currently has three major vegetation zones: deciduous hardwood forest $200-700 \mathrm{~m}$, coniferous forests 750 $1450 \mathrm{~m}$, and alpine tundra $>1450 \mathrm{~m}$ (Bormann et al. 1970, Reiners and Lang 1979, Spear 1981). We have 
studied pollen and plant macrofossils in radiocarbondated sediment cores from nine ponds ranging in elevation from 213 to $1538 \mathrm{~m}$ (Fig. 1). By comparing fossil and modern pollen percentages and influx, and by comparing the distributions of macrofossils of the corresponding species, we have pieced together a 14000 -yr history of vegetational changes along the elevational gradient from mixed hardwood forests through alpine tundra. Some of our preliminary results have been published (Likens and Davis 1975, Davis et al. 1980, Davis 1985), as has a detailed report on the history of high-elevation tundra and subalpine vegetation (Spear 1989). Jackson (1989) and Jackson and Whitehead (1991) have completed a comparable Holocene vegetation history along an elevational gradient from northern hardwood forests to subalpine fir forests in the Adirondack Mountains of New York.

The White Mountains present an opportunity to examine the temporal continuity of several montane plant communities, especially the coniferous spruce-fir forest, on a regional or local scale. Ecologists have traditionally considered the high-elevation forests of the White Mountains as a "southern extension of the boreal forest" (Oosting and Billings 1951) or as remnants of the spruce forest ("boreal forest") that moved northward as the late-Wisconsinan ice sheet retreated, implying continuity of boreal forest communities in space and time. More recently pollen data compiled from many sites throughout eastern North America show that on a continental scale, spruce pollen was rare in boreal regions 9000-5000 yr ago. The dominance of spruce trees within the boreal forest biome is a recent phenomenon in eastern North America (Bernabo and Webb 1977, Webb et al. 1983, Webb 1986). We will investigate whether the dominance of spruce in a vegetation zone on the mountain slopes is also a recent phenomenon.

The White Mountain record could also provide evidence on the equilibrium of plant distributions with climate. Davis (1976, 1981b) and MacDonald (1984) have argued that seed dispersal and establishment rather than climate may have limited the rate of expansion of trees northward following glaciation. Recent computer experiments show, however, that the past distributions of pollen in eastern North America can be predicted by applying pollen/climate transfer functions to output from General Circulation Models. This result suggests strongly that on a continental and millennial scale climate was the major factor controlling the distributions of trees (Webb et al. 1987). Tests of dispersal vs. climatic limitation on a regional scale have been ambiguous (Davis et al. 1986). An elevational transect, where the climatic gradient is compressed in space, minimizes the migration issue and should allow a more rigorous examination of the equilibrium question (Prentice 1986).

Finally, this vertical transect of sites provides us with new insights into factors affecting forest communities that would not have been apparent from the record at a single site. Soil development, disturbances by fire, pathogens, and wind, and climatic changes, especially complex shifts in temperature and moisture along the altitudinal gradient, are factors that may help to explain the shifting patterns of montane plant communities in the White Mountains over the last $14000 \mathrm{yr}$.

We have three objectives in this study: (1) to reconstruct the vegetation history of the mountain slopes and examine the continuity of vegetation zonation; (2) to search for evidence of equilibria of plant distributions with climate; and (3) to understand how exogenous environmental factors have influenced the vegetation history in the White Mountians.

\section{MethodS}

To help interpret the fossil record we analyzed the modern vegetation and pollen rain in the White Mountains and central New England.

\section{Modern vegetation survey}

We sampled the vegetation in a series of plots along two elevational transects: the east-facing slopes of Mount Washington in the Ellis River Valley, and the north slope of Mount Madison. Single plots on the first transect were circular, with radius of $10 \mathrm{~m}$. Paired plots on the second transect were rectangular $(4 \times 25 \mathrm{~m})$ plots. We calculated relative importance values for the trees along the transects; importance value equals relative density (proportion of individual stems) + relative frequency (proportion of plots at that elevation in which it occurs) + relative dominance (proportion of basal area). For easier comparison with pollen percentage diagrams we relativized the importance values of the trees and plotted them as percentages vs. elevation.

\section{Modern pollen rain: surface samples}

To determine the relationship between vegetation and its pollen record, modern and pre-European pollen assemblages were studied from 34 lakes and two alpine moss polsters in New Hampshire and Massachusetts (Table 1). A much more extensive series of high-elevation samples has been discussed by Spear (1989). Short cores (uppermost 0.5-1.0 m) of sediment were obtained with either a Davis-Doyle (1969) piston sampler or a Phleger (1955) sampler.

\section{Study sites}

Fig. 1 and Table 1 give the locations of the six paleoecological study sites: Mirror Lake $(213 \mathrm{~m})$, Lost Pond (625 m), Little East Pond (793 m), Lonesome Lake (831 m), Carter Notch Pond (1004 m), and Lake of the Clouds (1542 m). Kinsman Pond (1142 m), Eagle Lake (1275 m), Deer Lake Bog (1325 m), and Lake of the Clouds $(1542 \mathrm{~m})$ are discussed by Spear (1989). The Mirror Lake core collection methods have been 
TABLE 1. New Hampshire study sites (elevations and areas of the ponds were determined from field measurements and USGS $7 \frac{1}{2} 2^{\prime}$ topographic maps).

\begin{tabular}{|c|c|c|c|c|c|c|c|}
\hline Site & Location & $\begin{array}{l}\text { Elevation } \\
\quad(\mathrm{m})\end{array}$ & $\begin{array}{c}\text { Vegeta- } \\
\text { tion } \\
\text { type* }\end{array}$ & $\begin{array}{c}\text { Sample } \\
\text { type }\end{array}$ & $\begin{array}{l}\text { Area } \\
\text { (ha) }\end{array}$ & $\begin{array}{l}\text { Water } \\
\text { depth } \\
\text { (m) }\end{array}$ & $\begin{array}{c}\text { Core } \\
\text { length } \\
(\mathrm{m})\end{array}$ \\
\hline \multicolumn{8}{|c|}{ A) Paleoecological study sites } \\
\hline Mirror Lake & $\begin{array}{l}43^{\circ} 56^{\prime} \mathrm{N} \\
71^{\circ} 42.5^{\prime} \mathrm{W}\end{array}$ & 213 & 2 & LC & 15 & 10 & 12.4 \\
\hline Lost Pond & $\begin{array}{l}44^{\circ} 15^{\prime} \mathrm{N} \\
71^{\circ} 35^{\prime} \mathrm{W}\end{array}$ & 625 & 2 & LC & 1 & 1 & 5.5 \\
\hline Little East Pond & $\begin{array}{l}44^{\circ} 01^{\prime} \mathrm{N} \\
71^{\circ} 35^{\prime} \mathrm{W}\end{array}$ & 793 & 4 & LC & 1.4 & 1.4 & 4.7 \\
\hline Lonesome Lake & $\begin{array}{l}44^{\circ} 08^{\prime} \mathrm{N} \\
71^{\circ} 12^{\prime} \mathrm{W}\end{array}$ & 831 & 4 & $\mathrm{LC}$ & 5.2 & 2.7 & 4.4 \\
\hline Carter Notch Pond & $\begin{array}{l}44^{\circ} 16^{\prime} \mathrm{N} \\
71^{\circ} 12^{\prime} \mathrm{W}\end{array}$ & 1004 & 4 & LC & 0.5 & $\begin{array}{l}3.2 \\
2.4\end{array}$ & $\begin{array}{l}5.5 \\
6.7\end{array}$ \\
\hline Kinsman Pond & $\begin{array}{l}44^{\circ} 8^{\prime} \mathrm{N} \\
71^{\circ} 44^{\prime} \mathrm{W}\end{array}$ & 1140 & 5 & LC & 1.9 & 3 & 3.4 \\
\hline Eagle Lake Bog & $\begin{array}{l}44^{\circ} 10^{\prime} \mathrm{N} \\
71^{\circ} 40^{\prime} \mathrm{W}\end{array}$ & 1275 & 5 & $\mathrm{LC}$ & 0.14 & 1 & 4.2 \\
\hline Deer Lake Bog & $\begin{array}{l}44^{\circ} 1.5^{\prime} \mathrm{N} \\
71^{\circ} 50^{\prime} \mathrm{W}\end{array}$ & 1325 & 5 & LC & 0.1 & 0 & 4.9 \\
\hline Lake of the Clouds & $\begin{array}{l}44^{\circ} 15^{\prime} \mathrm{N} \\
71^{\circ} 15^{\prime} \mathrm{W}\end{array}$ & 1542 & 6 & $\mathrm{LC}$ & 0.4 & $\begin{array}{l}1.5 \\
1.5\end{array}$ & $\begin{array}{l}2.5 \\
2.9\end{array}$ \\
\hline \multicolumn{8}{|c|}{ B) Modern and presettlement study sites } \\
\hline Turtle Pond & $\begin{array}{l}43^{\circ} 15^{\prime} \mathrm{N} \\
71^{\circ} 31^{\prime} \mathrm{W}\end{array}$ & 98 & 1 & $\mathrm{SC}$ & & & \\
\hline Sandogardy Pond & $\begin{array}{l}43^{\circ} 23^{\prime} \mathrm{N} \\
71^{\circ} 37^{\prime} \mathrm{W}\end{array}$ & 107 & 1 & LC & & & \\
\hline Keyser Lake & $\begin{array}{l}43^{\circ} 15^{\prime} \mathrm{N} \\
71^{\circ} 42^{\prime} \mathrm{W}\end{array}$ & 132 & 1 & $\mathrm{SC}$ & & & \\
\hline Loon Lake & $\begin{array}{l}43^{\circ} 47.5^{\prime} \mathrm{N} \\
71^{\circ} 45^{\prime} \mathrm{W}\end{array}$ & 138 & 2 & SC & & & \\
\hline Campton Pond & $\begin{array}{l}43^{\circ} 52^{\prime} \mathrm{N} \\
71^{\circ} 37^{\prime} \mathrm{W}\end{array}$ & 194 & 2 & SS & & & \\
\hline Bartlett Bog & $\begin{array}{l}44^{\circ} 6^{\prime} \mathrm{N} \\
71^{\circ} 12.5^{\prime} \mathrm{W}\end{array}$ & 200 & 2 & LC & & & \\
\hline Perch Lake & $\begin{array}{l}43^{\circ} 48^{\prime} \mathrm{N} \\
71^{\circ} 34^{\prime} \mathrm{W}\end{array}$ & 308 & 3 & SC & & & \\
\hline Monomonac Lake & $\begin{array}{l}42^{\circ} 41^{\prime} \mathrm{N} \\
72^{\circ} 00^{\prime} \mathrm{W}\end{array}$ & 342 & 1 & $\mathrm{SC}$ & & & \\
\hline Ellesworth Pond & $\begin{array}{l}43^{\circ} 52^{\prime} \mathrm{N} \\
71^{\circ} 45^{\prime} \mathrm{W}\end{array}$ & 343 & 3 & SS & & & \\
\hline Queen Lake & $\begin{array}{l}42^{\circ} 52^{\prime} \mathrm{N} \\
72^{\circ} 09^{\prime} \mathrm{W}\end{array}$ & 352 & 1 & SS & & & \\
\hline Stinson Lake & $\begin{array}{l}43^{\circ} 52^{\prime} \mathrm{N} \\
71^{\circ} 39^{\prime} \mathrm{W}\end{array}$ & 400 & 3 & SS & & & \\
\hline Hall Pond & $\begin{array}{l}43^{\circ} 52^{\prime} \mathrm{N} \\
71^{\circ} 32^{\prime} \mathrm{W}\end{array}$ & 415 & 3 & SS & & & \\
\hline Russel Pond & $\begin{array}{l}44^{\circ} 0.5^{\prime} \mathrm{N} \\
71^{\circ} 39^{\prime} \mathrm{W}\end{array}$ & 508 & 3 & SC & & & \\
\hline Beaver Lake & $\begin{array}{l}44^{\circ} 2^{\prime} \mathrm{N} \\
71^{\circ} 48^{\prime} \mathrm{W}\end{array}$ & 585 & 3 & $\mathrm{SC}$ & & & \\
\hline Echo Lake & $\begin{array}{l}44^{\circ} 10^{\prime} \mathrm{N} \\
71^{\circ} 42^{\prime} \mathrm{W}\end{array}$ & 610 & 3 & $\mathrm{SC}$ & & & \\
\hline Long Pond & $\begin{array}{l}44^{\circ} 3^{\prime} \mathrm{N} \\
71^{\circ} 53^{\prime} \mathrm{W}\end{array}$ & 677 & 3 & $\mathrm{SC}$ & & & \\
\hline Shoal Pond & $\begin{array}{l}44^{\circ} 10^{\prime} \mathrm{N} \\
71^{\circ} 28^{\prime} \mathrm{W}\end{array}$ & 785 & 4 & $\mathrm{SC}$ & & & \\
\hline Norcross Pond & $\begin{array}{l}44^{\circ} 7^{\prime} \mathrm{N} \\
71^{\circ} 24^{\prime} \mathrm{W}\end{array}$ & 938 & 4 & SC & & & \\
\hline Nancy Pond & $\begin{array}{l}44^{\circ} 6.5^{\prime} \mathrm{N} \\
71^{\circ} 24^{\prime} \mathrm{W}\end{array}$ & 948 & 4 & SC & & & \\
\hline $\begin{array}{l}\text { Moss (Mt. Washington } \\
\text { summit) }\end{array}$ & $\begin{array}{l}44^{\circ} 16^{\prime} \mathrm{N} \\
71^{\circ} 20^{\prime} \mathrm{W}\end{array}$ & 1907 & 6 & SS & & & \\
\hline
\end{tabular}


TABLE 1. Continued.

\begin{tabular}{|c|c|c|c|c|c|c|c|}
\hline Site & Location & $\begin{array}{l}\text { Elevation } \\
\text { (m) }\end{array}$ & $\begin{array}{c}\text { Vegeta- } \\
\text { tion } \\
\text { type* }\end{array}$ & $\begin{array}{c}\text { Sample } \\
\text { typet }\end{array}$ & $\begin{array}{l}\text { Area } \\
\text { (ha) }\end{array}$ & $\begin{array}{c}\text { Water } \\
\text { depth } \\
\text { (m) }\end{array}$ & $\begin{array}{c}\text { Core } \\
\text { length } \\
\text { (m) }\end{array}$ \\
\hline Hermit Lake & $\begin{array}{l}44^{\circ} 14^{\prime} \mathrm{N} \\
71^{\circ} 17^{\prime} \mathrm{W}\end{array}$ & 1200 & 5 & $\mathrm{SC}$ & & & \\
\hline Spaulding Pond & $\begin{array}{lll}44^{\circ} 17^{\prime} \mathrm{N} \\
71^{\circ} 20^{\prime} \mathrm{W}\end{array}$ & 1243 & 5 & SS & & & \\
\hline Star Lake Bog & $\begin{array}{l}44^{\circ} 19.5^{\prime} \mathrm{N} \\
71^{\circ} 17^{\prime} \mathrm{W}\end{array}$ & 1440 & 6 & SC & & & \\
\hline Mascoma Lake & $\begin{array}{l}43^{\circ} 37^{\prime} \mathrm{N} \\
72^{\circ} 10^{\prime} \mathrm{W}\end{array}$ & & 2 & $\mathrm{SC}$ & & & \\
\hline
\end{tabular}

* Vegetation type code: 1-central hardwood forest; 2-mixed hardwoods with white pine and hemlock; 3-northern hardwoods; 4-spruce-fir; 5-subalpine fir; 6-alpine tundra.

$\dagger \mathrm{LC}=$ Long Core; $\mathrm{SC}=$ Short Core; $\mathrm{SS}=$ Surface.

reported elsewhere (Likens and Davis 1975, Davis and Ford 1982). The other sites were sampled near the center of the basin using a $5 \mathrm{~cm}$ diameter Livingstone piston sampler (Wright et al. 1965) from a raft firmly tied to shore. Additional cores were collected at Carter Notch Pond from the ice in late winter.

\section{Core processing: pollen, calibrations, macrofossils, and dating}

One-millilitre samples for pollen analysis were prepared using standard digestion procedures: $\mathrm{HCl} ; \mathrm{KOH}$; HF; and acetolysis (Faegri and Iverson 1975). Residues from highly inorganic sediments were further concentrated by sieving fine particles through $10-\mu \mathrm{m}$ Nitex screening (Cwynar et al. 1979). Estimates of pollen concentration were made from the ratio of native pollen to marker Eucalyptus pollen (Stockmarr 1971). The conventions used in categorizing the pollen and spores followed those of Cushing (1963). The pollen sum for each sample was usually 300-500 grains and included pollen and spores of all terrestrial taxa.

Macrofossil samples of $50 \mathrm{~mL}(2.5-\mathrm{cm}$ core segments) were prepared following procedures outlined by Spear (1989). The sediment was heated in soapy water and washed through a series of three U.S. Standard Series Sieves: $595-\mu \mathrm{m}$ mesh (Number 30), 250$\mu \mathrm{m}$ mesh (Number 60), and 90- $\mu \mathrm{m}$ mesh (Number 170). All fragments from the $595-\mu \mathrm{m}$ and $250-\mu \mathrm{m}$ mesh sieves and subsamples from the $90-\mu \mathrm{m}$ mesh sieve were examined at $12 \times$ or $25 \times$, respectively. The results are

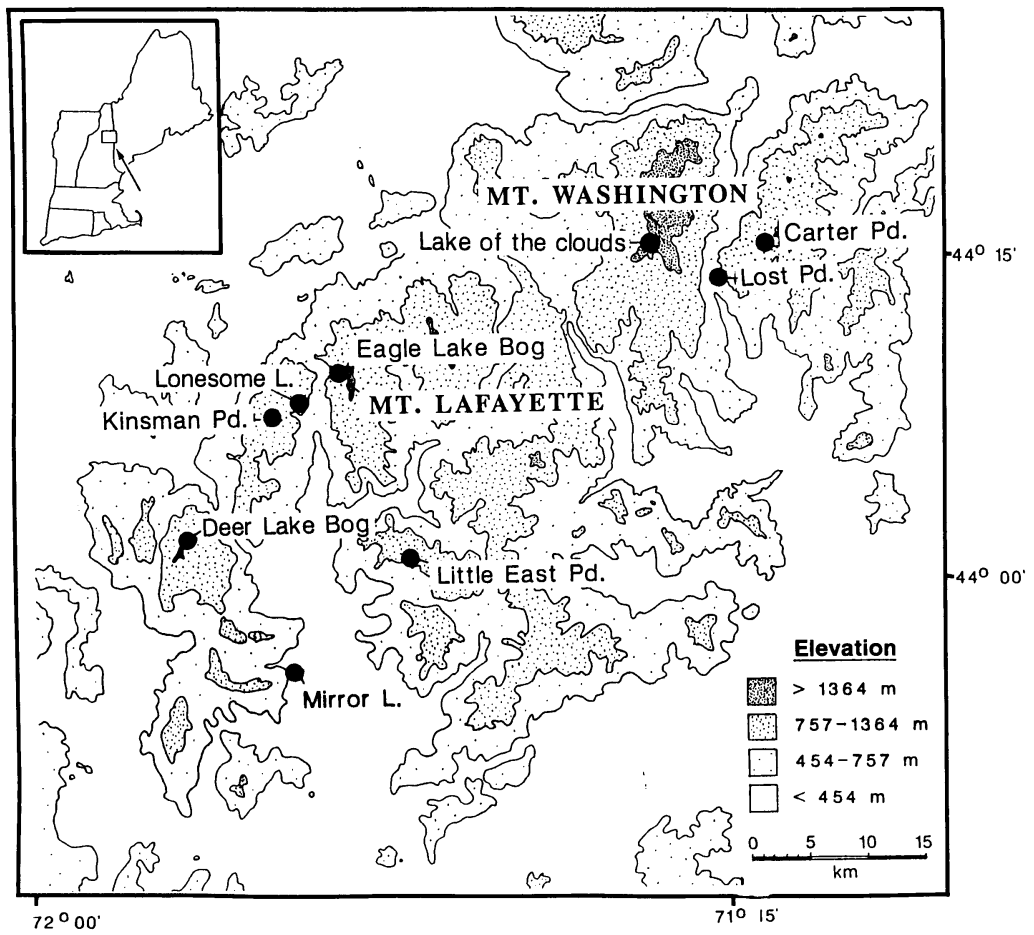

Fig. 1. Map of White Mountains study area showing elevations, site locations, and mountain massifs. 
TABle 2. Radiocarbon dates at White Mountain sites. (Radiocarbon dates and sedimentation curves for Mirror Lake are reported in Likens and Davis [1975] and Davis and Ford [1982]. Radiocarbon dates and sedimentation curves for Lake of the Clouds are reported in Spear [1989].)

\begin{tabular}{cllc}
\hline \hline Site & Depth $(\mathrm{m})$ & Sample no. & Age \\
\hline Lost Pond & $1.07-118$ & I-9899 & $2235 \pm 80$ \\
$(650 \mathrm{~m})$ & $3.58-3.67$ & I-9900 & $8320 \pm 130$ \\
& $3.96-4.04$ & QL-984 & $8920 \pm 160$ \\
& $4.49-4.60$ & I-9901 & $10250 \pm 140$ \\
& $4.88-5.08$ & QL-985 & $12870 \pm 370$ \\
Lonesome Lake & $0.70-0.88$ & GX-5424 & $1960 \pm 125$ \\
$(900 \mathrm{~m})$ & $1.70-1.87$ & GX-5425 & $4250 \pm 165$ \\
& $3.24-3.40$ & GX-5426 & $9415 \pm 225$ \\
& $3.45-3.65$ & GX-5427 & $10610 \pm 310$ \\
Carter Notch & $3.68-4.05$ & GX-5428 & $10535 \pm 495$ \\
Pond (1004 m) & $1.24-1.36$ & I-9902 & $1655 \pm 80$ \\
& $4.64-4.77$ & I-9903 & $6685 \pm 110$ \\
& $5.74-5.86$ & I-9904 & $8570 \pm 130$ \\
\hline
\end{tabular}

plotted as concentrations of fragments per $50 \mathrm{~mL}$ of sediment. The "minimum needle number" (Delcourt 1978) was plotted on the summary macrofossil diagrams. Macrofossil samples from Mirror Lake were taken from Core 783, a core collected in $6 \mathrm{~m}$ of water near shore (Davis and Ford 1982).

Bulk samples for radiocarbon dating were removed from the cores and scraped to remove surface contamination. Table 2 summarizes the radiocarbon dates of samples. The age-depth relationship of the sediment cores at Lost Pond, Lonesome Lake, and Carter Notch Pond were determined by linear regression of radiocarbon-dated or pollen-dated (hemlock decline at 4500 yr BP) (Allison et al. 1986) levels against depth (Fig. 2). Likens and Davis (1975) show the age-depth relationship for the central core at Mirror Lake; Davis and Ford (1982) show the relationship for cores 782 and 783. Spear (1989) provides information on Lake of the Clouds. Ages of sediment at Little East Pond were estimated by correlating the pollen stratigraphy with the other sites.

Pollen influx in the short cores was estimated by dividing postsettlement pollen concentrations by the sediment accumulation rate (years per centimetre). The 19th century hemlock (Tsuga canadensis) pollen decrease, which records the tanbark harvest $(\approx 1830)(\mathrm{Li}-$ kens 1985), was used as a standard horizon to determine the rate of sediment accumulation. For southern New Hampshire and central Massachusetts, a date of 1780 was used for the herb pollen increase.

\section{RESULTS \\ Modern vegetation}

The vegetation sampled along the transects (Fig. 3) can be divided into four elevational zones based on relative importance values. (1) Mixed hardwoods ( $<450$ $\mathrm{m}$ ): white pine (Pinus strobus) and hemlock (Tsuga canadensis) grow together with red oak (Quercus rubra), sugar maple (Acer saccharum), and beech (Fagus grandifolia). (2) Northern hardwoods $(\approx 450-750 \mathrm{~m})$ : above $400-600 \mathrm{~m}$ elevation, first white pine and oak and then hemlock disappear from the forest. Bormann et al. (1970) give the upper limits for red oak and white pine as $415 \mathrm{~m}$, and hemlock $650 \mathrm{~m}$. Although scattered individuals of these species grow at higher elevation on south-facing granite ledges, our transect data agree with the previously described elevation limits. The stands above $600 \mathrm{~m}$ are dominated by sugar maple, beech, and yellow birch (Betula lutea). Red spruce (Picea rubens) and fir (Abies balsamea) can be locally im-

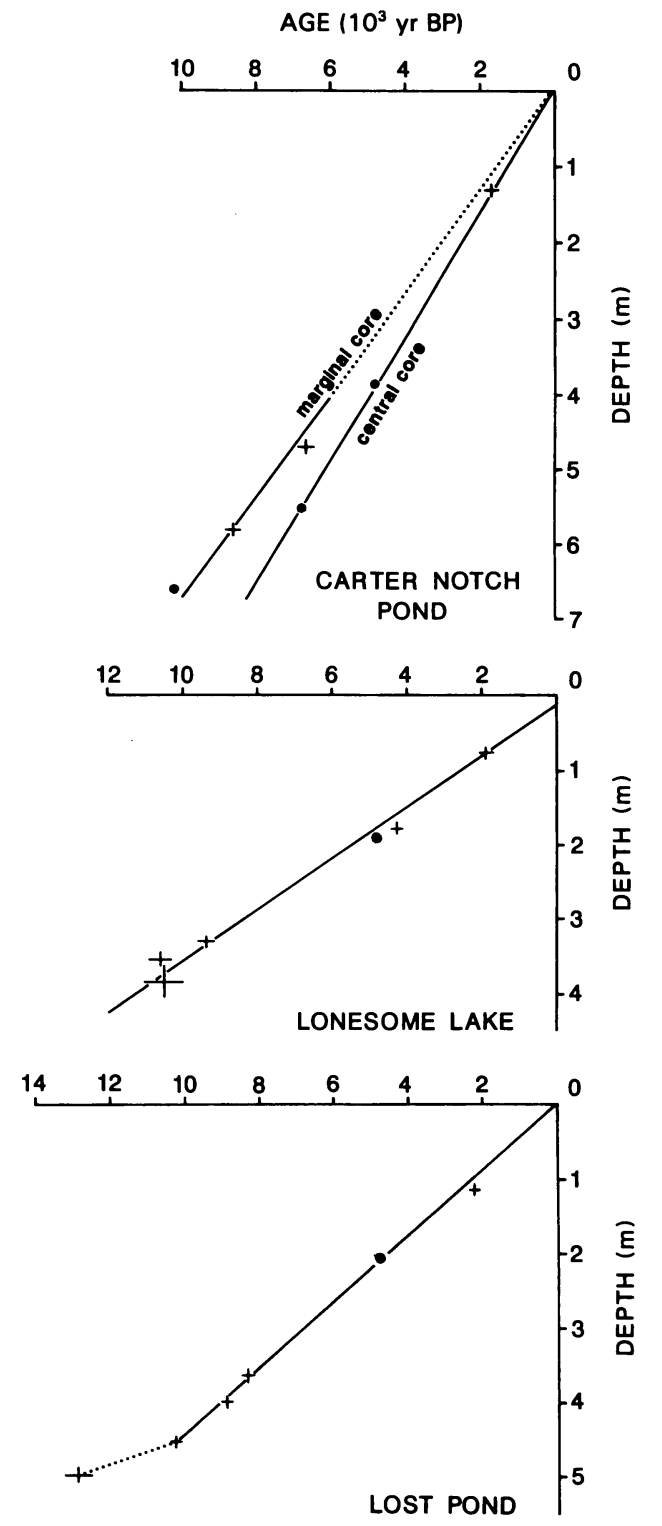

Fig. 2. Linear regression of age vs. depth at three of the study sites: Lost Pond, Lonesome Lake, and Carter Notch Pond. (Pollen stratigraphy was used to correlate the central and marginal cores at Carter Notch Pond. The pollen and macrofossil diagrams of Carter represent a composite of the two cores.) 

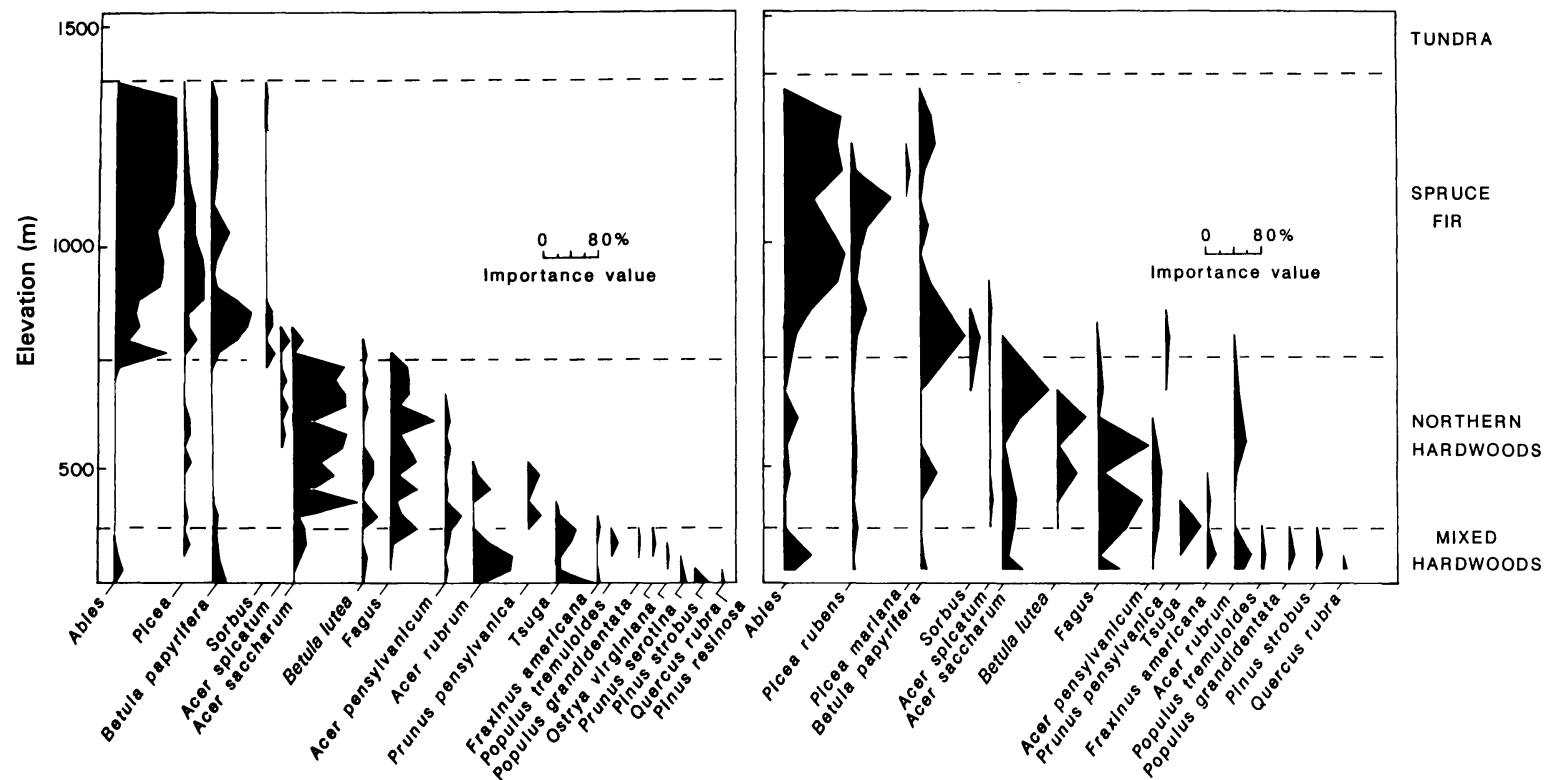

Fig. 3. Vegetation zonation based on transects from north and east slopes in the study area. Importance values have been rescaled and presented as percentages.

portant along streams. (3) Spruce/fir (750-1450 m): an abrupt change from predominantly deciduous to predominantly coniferous forest at $\approx 750 \mathrm{~m}$ is shown in our transects. The coniferous zone is patchy, with stands of paper birch (Betula papyrifera) in recently disturbed areas. At lower elevations (750-1100 m) red spruce is an important species, whereas at higher elevations $(900$ $1400 \mathrm{~m}$ ) balsam fir becomes the dominant tree species, forming a forest limit at elevations that vary according to topographic position. (4) Alpine tundra (>1450 m): above $\approx 1450 \mathrm{~m}$ there is treeless tundra vegetation. A more detailed description of the high-elevation conifer forest and tundra is given by Spear (1989).

\section{Modern pollen rain: surface samples}

Fig. 1 is a generalized contour map of the mountains, providing a view of the area occupied by the four major vegetation zones (although the correlation with elevation is not perfect). Average pollen percentages in surface sediments from short cores from 34 lakes and two bogs are shown plotted against the elevations of the sites in Fig. 4. These results illustrate a common problem in the pollen record of mountainous regions: vegetation zones fail to produce distinctive pollen assemblages because of vertical pollen transport (Markgraf 1980, Solomon and Silkworth 1986, Gaudreau et al. 1989).

Herb pollen percentages are relatively high (7-20\%) in surface samples from above tree line, but most of the herb pollen is ragweed (Ambrosia) blown upward from lower elevations. Herb pollen percentages in presettlement assemblages are similar at all elevations (Fig.
4). Other differences show more clearly: high percentages of spruce and fir pollen characterize assemblages from the spruce-fir forests between 750 and $1450 \mathrm{~m}$ elevation. Assemblages from the northern hardwood forest below $750 \mathrm{~m}$ have higher percentages of hemlock, beech, and maple pollen. Pine and oak pollen is more abundant at very low elevations, where these genera occur in the local vegetation. This increase in pine and oak is particularly obvious in samples from southern New Hampshire and central Massachusetts where pine, oak, and hemlock are more abundant in the forest vegetation. However, in general, pollen percentages are relatively insensitive to the changes in vegetation with elevation. The pollen source area is much larger than the area of each vegetation zone (Gaudreau et al. 1989, Jackson and Whitehead 1991).

Influx rates vary with elevation, showing characteristic differences in different vegetation zones. We calculated average annual pollen influx since 1830 for 16 lakes (Table 3). Influx rates from lakes surrounded by deciduous forest clustered around 25 000-30000 grains $\cdot \mathrm{cm}^{-2} \cdot \mathrm{yr}^{-1}$, although there are several very low values. The low values are similar to those found in peat deposits where no sediment focusing occurs (Middeldorp 1986). Influx values from lakes in spruce-fir forest and tundra averaged 12500 grains $\cdot \mathrm{cm}^{-2} \cdot \mathrm{yr}^{-1}$, a value similar to lakes in boreal regions (Davis et al. 1973). Slightly higher values at Lake of the Clouds, which is above tree line, may reflect sediment focusing (Davis and Ford 1982), because in this lake only the central half of the basin accumulates sediment (Spear 1981). The influx rates suggest that spruce-fir forest 

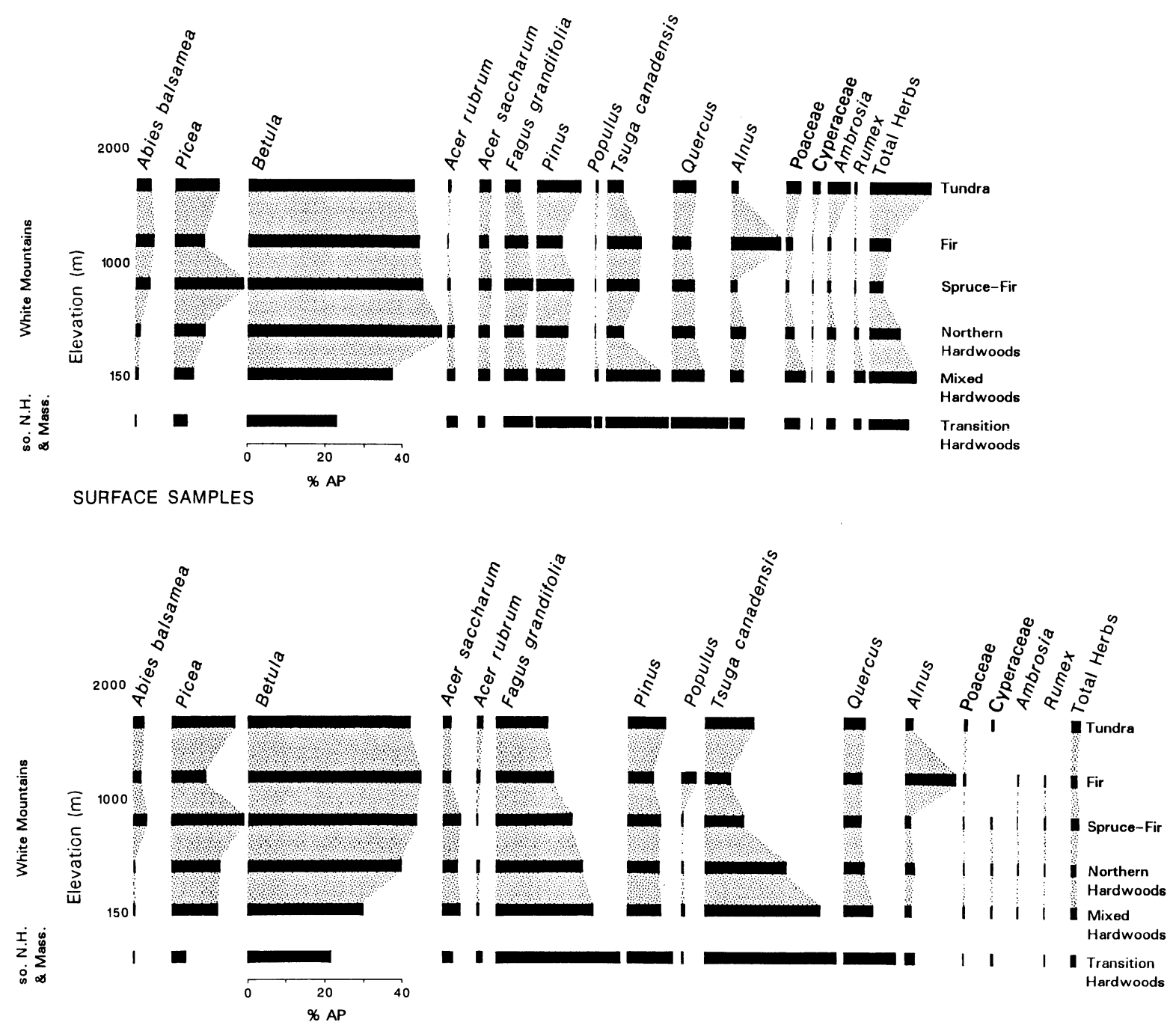

Fig. 4. Average pollen percentages of major taxa from the vegetation zones of the study area: surface sample data, and immediate pre-European settlement data.

and tundra produce fewer pollen grains than deciduous forest at lower elevations. This explains the high percentage values for wind-transported low-elevation pollen types (e.g., ragweed and pine) at high-elevation sites.

Based on these results, we expected that fossil pollen stratigraphic records would be similar in all sites along the transect, giving little information about local forest abundances. Therefore, in developing our interpretations, we placed more reliance on the fossil record of poorly dispersed pollen, such as fir and larch (Larix laricina), on macrofossils, which have a much smaller source area than pollen (Dunwiddie 1987, Gaudreau et al. 1989, Jackson 1989), and on pollen influx, which does change with elevation.

We also accept the interpretation that fossil pollen assemblages quantitatively different from any on the modern transect imply past differences in abundances of species at some (probably all) elevations.

\section{Paleoecological record}

Both pollen percentage and influx diagrams from the White Mountains show the stratigraphy identified in other regions of New England (Deevey 1943, 1951, 1958, Gaudreau and Webb 1985) (Figs. 5-7). Although we have not zoned the diagrams, preferring instead to use the time scale directly, the discussion will be organized according to four time periods. Note that the boundaries of these time periods do not correspond exactly to the four pollen zones identified in New England by Deevey $(1943,1958)$ and subsequent authors (Davis 1965, Gaudreau and Webb 1985). Sites will be discussed from lowest to highest elevation.

13 700-11500 yr BP (Tundra [T] Zone [Leopold 1956]). - By 13000 yr BP sedimentation had started in four lake basins: Mirror Lake (200 m), Lost Pond $(650 \mathrm{~m})$, Deer Lake Bog $(1325 \mathrm{~m})$, and Lake of the 
TABLE 3. Average annual pollen accumulation in short-core sediments.

\begin{tabular}{|c|c|c|c|}
\hline Vegetation & $\begin{array}{l}\text { Eleva- } \\
\text { tion } \\
(\mathrm{m})\end{array}$ & Site name & $\begin{array}{c}\text { Pollen } \\
\text { influx } \\
\text { (grains } \\
\mathrm{cm}^{-2} \text {. } \\
\mathrm{yr}^{-1} \text { ) }\end{array}$ \\
\hline $\begin{array}{l}\text { Transition hardwoods } \\
\text { (Southern New } \\
\text { Hampshire and } \\
\text { Massachusetts) }\end{array}$ & $\begin{array}{r}351 \\
107 \\
137 \\
97\end{array}$ & $\begin{array}{l}\text { Queen Lake } \\
\text { Sandogardy Pond } \\
\text { Keyser Pond } \\
\text { Turtle Pond }\end{array}$ & $\begin{array}{r}31750 \\
21022 \\
1745 \\
9122\end{array}$ \\
\hline $\begin{array}{l}\text { Northern hardwoods } \\
\text { (with white pine } \\
\text { and hemlock) }\end{array}$ & $\begin{array}{l}148 \\
305 \\
207 \\
251\end{array}$ & $\begin{array}{l}\text { Loon Lake } \\
\text { Perch Pond } \\
\text { Mirror Lake } \\
\text { Hancock Pond } \\
\text { (southern New } \\
\text { Hampshire) }\end{array}$ & $\begin{array}{r}7800 \\
25278 \\
27275 \\
20130\end{array}$ \\
\hline Northern hardwoods & $\begin{array}{l}503 \\
610 \\
671 \\
778\end{array}$ & $\begin{array}{l}\text { Russel Pond } \\
\text { Echo Lake } \\
\text { Long Pond } \\
\text { Shoal Pond }\end{array}$ & $\begin{array}{r}1745 \\
26465 \\
14512 \\
25478\end{array}$ \\
\hline Spruce/fir & $\begin{array}{r}844 \\
1006 \\
1204\end{array}$ & $\begin{array}{l}\text { Lonesome Lake } \\
\text { Carter Notch } \\
\text { Hermit Lake }\end{array}$ & $\begin{array}{r}8350 \\
12808 \\
14400\end{array}$ \\
\hline $\begin{array}{l}\text { Alpine tundra } \\
\text { (krummholz) }\end{array}$ & 1518 & Lake of the Clouds & 16000 \\
\hline
\end{tabular}

Clouds $(1542 \mathrm{~m})$. Sediments in this interval are characterized by: (1) high percentages of nonarboreal pollen; (2) low and roughly equal percentages of spruce and pine (mostly diploxylon type) pollen; (3) extremely low pollen influx ( $<600$ grains $\left.\cdot \mathrm{cm}^{-2} \cdot \mathrm{yr}^{-1}\right)$; (4) a lack of plant macrofossils; (5) and high silt content (Davis and Ford 1982, Spear 1989). Shrub and herb pollen percentages are variable along the altitudinal transect of sites. Willow (Salix) percentages are higher at the low-elevation sites than they are at Lake of the Clouds. Birch (Betula) pollen was found in higher percentages $(10 \%)$ at Mirror Lake than at Lost Pond and sites at higher elevations. Dwarf birch was present in the region on the basis of macrofossils (Miller and Thompson 1979) and small-sized pollen grains (Spear 1989). Pollen from a group of shrubs, Juniperus/Thuja, Shepherdia canadensis, and Sanguisorba at Mirror Lake, and Ericaceae and Shepherdia canadensis at Lost Pond, were limited to the early late-glacial period before 11500 yr BP. There was no record of Shepherdia or Sanguisorba pollen and very little Ericaceae pollen at the highelevation sites. Herbaceous pollen types such as grass (Gramineae), Artemisia, Tubuliflorae, Ambrosia-type, and Caryophyllaceae occurred in higher percentages upslope.

The record of arctic-alpine fossils is sparse. Mirror Lake sediments, dated at $12800 \mathrm{yr}$ BP, yielded leaf fragments of Vaccinium uliginosum and Dryas integrifolia. Several pollen grains of Saxifragaceae, Campanula, and Epilobium were found in Lost Pond sediments in the late-glacial zone. Lake of the Clouds yielded grains of Campanula, Armeria, and Polemonium.
11 500-9000 yr BP (Mixed-Conifer Woodland Zone). - This zone spans the late-glacial/Holocene transition and is characterized by increasing pollen percentages and influx of arboreal taxa. Silt deposition declined, and sediments became more organic at Mirror Lake (Davis et al. 1985) and Lost Pond (Spear 1989). Sedimentation began $10500 \mathrm{yr}$ ago at Lonesome Lake and $9800 \mathrm{yr}$ ago at Carter Notch Pond; therefore, sites at all elevations along the transect provided data for at least one millennium of the MixedConifer Woodland Zone.

1. Spruce.-Spruce pollen percentages at Mirror Lake began to increase from less than $25 \%$ beginning 11500 yr ago, peaked at 53\% $10800 \mathrm{yr}$ ago, and dropped gradually to $1 \%$ by 9000 yr ago (Fig. 5). Pollen influx curves match the percentage profiles. Spruce needles were first found at Mirror Lake and Lost Pond in sediments dating from $11400 \mathrm{yr}$ ago and $11300 \mathrm{yr}$ ago, respectively (Fig. 8A). At Lost Pond, $450 \mathrm{~m}$ higher in elevation, the spruce pollen record is similar to Mirror Lake, although peak percentages and influx values were less than at Mirror Lake and the decline in spruce pollen and influx was steeper (Figs. 6 and 7). Spruce pollen was abundant in Lonesome Lake sediments from the beginning of the record, with maximum percentages and influx at $10100 \mathrm{yr}$ BP. Macrofossils were rare, but spruce needles occurred in a sample dating from $\approx 9900 \mathrm{yr}$ ago (Fig. 8A). The pollen percentage and influx profiles for spruce at Carter Notch Pond were virtually identical to Lonesome Lake. The values declined abruptly before $9000 \mathrm{yr}$ BP (Figs. 6 and 7). The macrofossil concentrations at Carter Notch, unlike Mirror Lake and Lonesome Lake, also showed this abrupt decline in spruce.

2. Juniperus/Thuja.-Juniperus/Thuja pollen reached peak percentage and influx values at about the same time as spruce.

3. Fir. - Fir pollen percentages at Mirror Lake remained below $1 \%$ until $10500 \mathrm{yr}$ BP, peaked at $8.3 \%$ $\approx 10000 \mathrm{yr} \mathrm{BP}$, and dropped to $\approx 2 \%$ by $9000 \mathrm{yr} \mathrm{BP}$ (Fig. 5). No fir macrofossils were found in Mirror Lake sediments during this time. Percentages and influx of fir pollen were lower at Lost Pond and Lonesome Lake than at Mirror Lake, but both sites had low numbers of fir macrofossils. The record of fir at Carter Notch Pond differed from records at the other mid-elevation sites. Percentages and influx of fir did not show a peak, but instead averaged $\approx 2 \%$, and 700 grains $\cdot \mathrm{cm}^{-2} \cdot \mathrm{yr}^{-1}$ throughout the interval (Figs. 6 and 7). Needle fragments were also present in this interval.

4. Larch. - Larch pollen is large and poorly dispersed; therefore, it is not surprising that the distribution of pollen and needle fragments is similar. Larch reached its highest percentage and influx values at Mirror Lake in sediments dating from 9900 yr BP (Figs. 5 and 7). Needle fragments were found in sediments dating from 9900 yr BP. Lost Pond had extremely low percentages of larch pollen; however, the presence of 

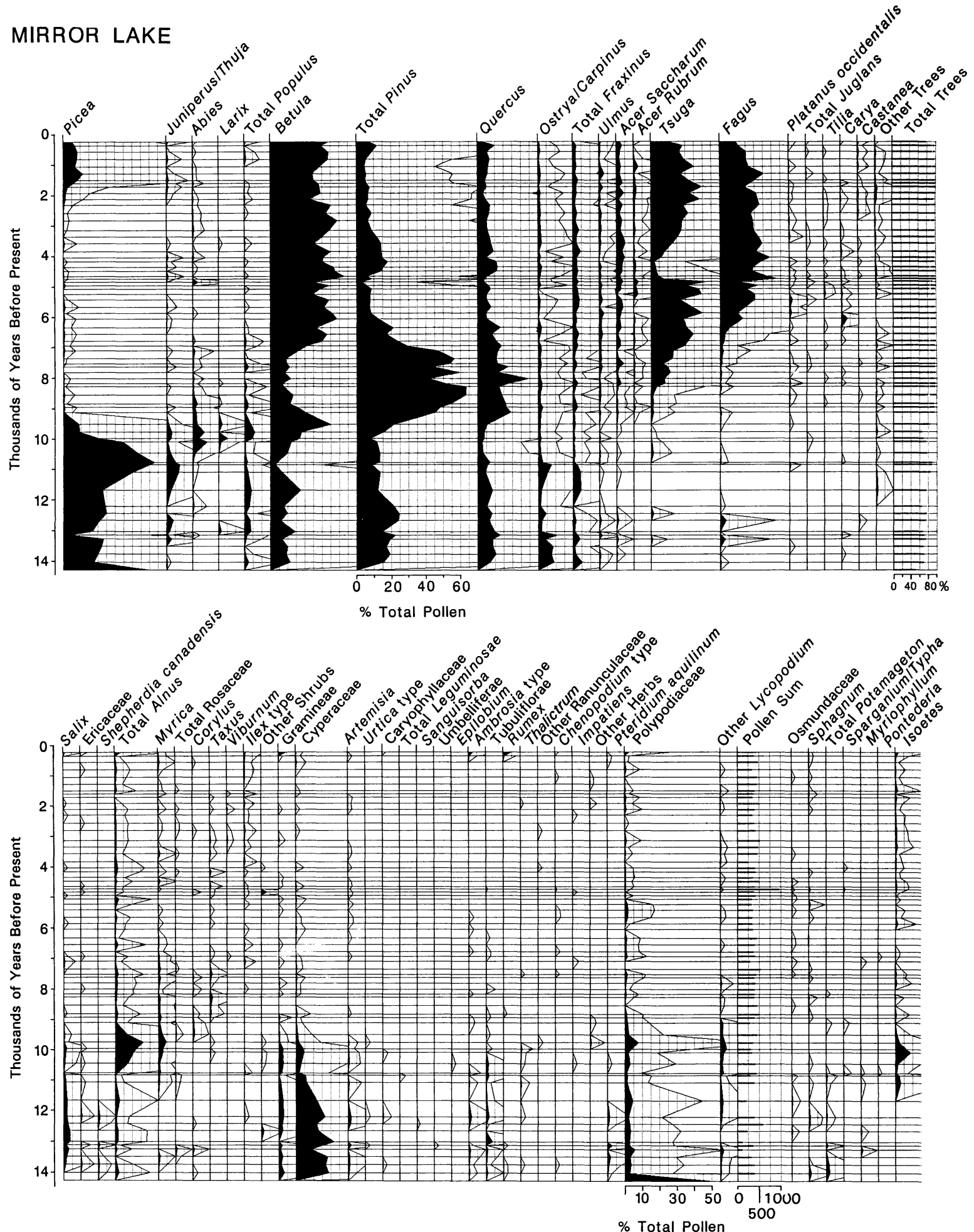

Fig. 5. Pollen percentage diagram: Mirror Lake $213 \mathrm{~m}$.

larch pollen was continuous from $10100 \mathrm{yr}$ ago to the end of the transition interval. Lonesome Lake, typically poor in macrofossils, had abundant larch needles in the $9600 \mathrm{yr}$ BP and $9000 \mathrm{yr}$ BP samples (Fig. 8A).
Kinsman Pond, $250 \mathrm{~m}$ higher in elevation and a few kilometres west of Lonesome Lake, had both pollen and macrofossils of larch in 9500-yr-old levels (Spear 1989). A few grains of larch pollen were found at Carter 


\section{CARTER NOTCH POND}

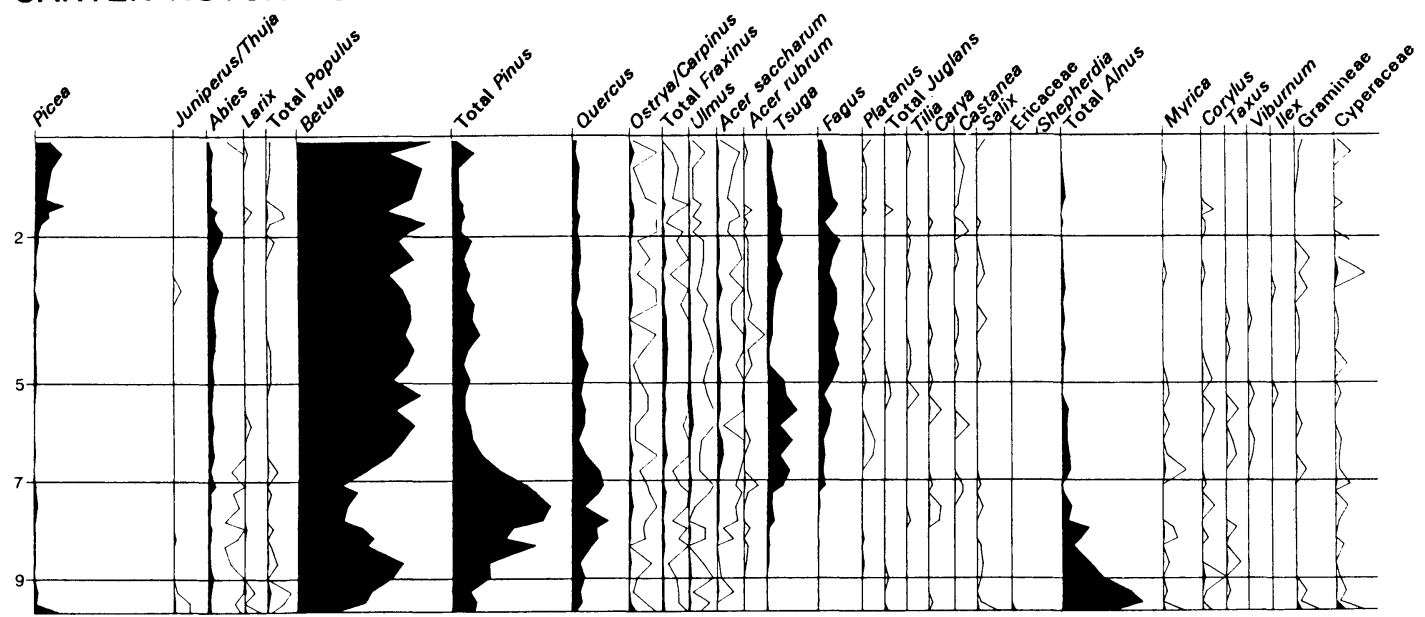

LONESOME LAKE

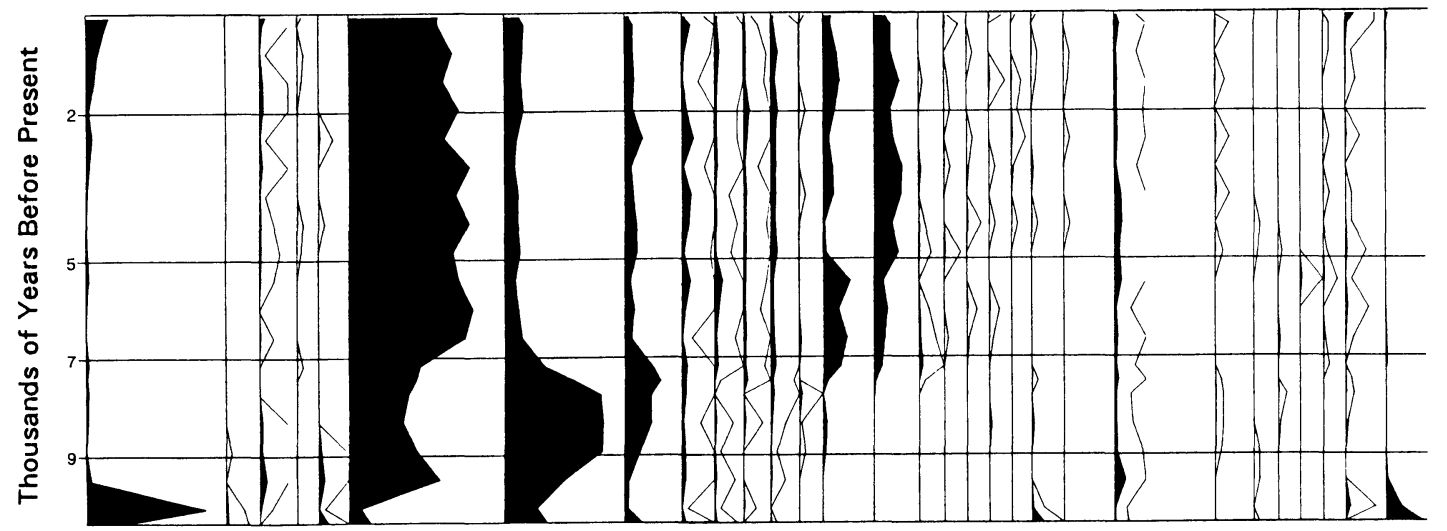

LOST POND

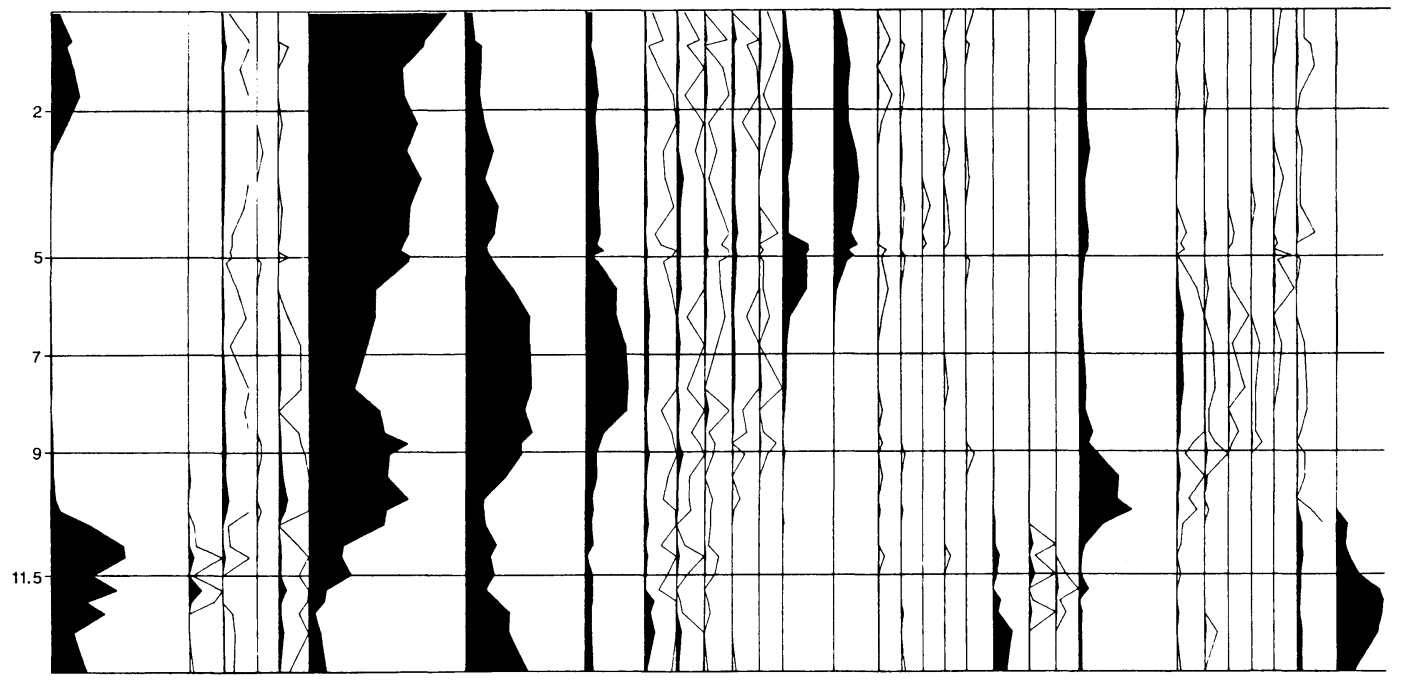

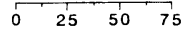

$\%$ Total Pollen

FIG. 6. Pollen percentage diagrams in elevational sequence with the lowest coring site at the bottom: Lost Pond $625 \mathrm{~m}$, Lonesome Lake $831 \mathrm{~m}$, and Carter Notch Pond $1004 \mathrm{~m}$. 

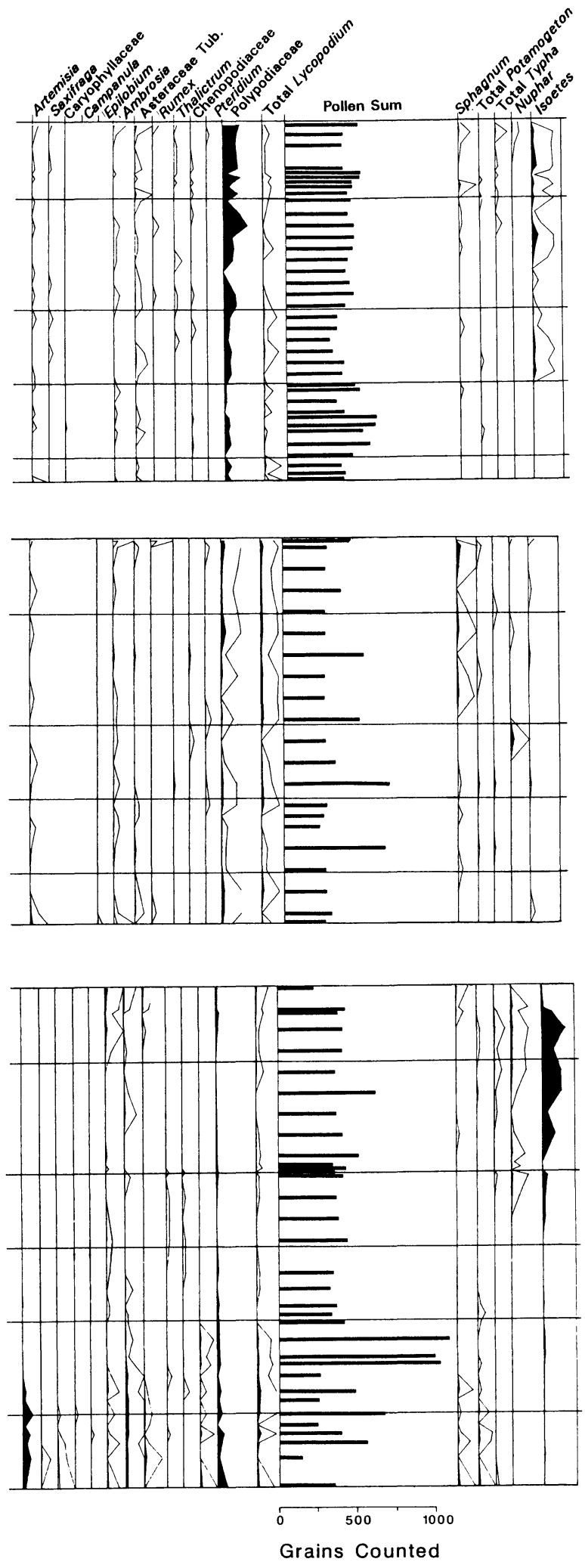

FIG. 6. Continued.
Notch Pond in the latter part of the transition period, 9800-9000 yr BP. Similar results were reported from Deer Lake Bog, $325 \mathrm{~m}$ above Carter Notch Pond (Spear 1989). No larch pollen grains were found at Lake of the Clouds, but needle fragments were found at the 10000 and $10250 \mathrm{yr}$ BP levels.

5. Birch. - Study sites at all elevations show an early (between 10000 and $9000 \mathrm{yr}$ BP) peak (40-50\%) in birch pollen percentages and influx rates (Figs. 5-7). Paper birch seeds first appear at four sites, Lost Pond, Lonesome Lake, Carter Notch Pond, and Kinsman Pond (Spear 1981), $\approx 9500$ yr ago (Fig. 8A). Yellow/ sweet $(\mathrm{y} / \mathrm{s})$ birch seeds (probably yellow birch considering modern distribution) were found at this time at Lost Pond and Lonesome Lake (Fig. 8B) but were outnumbered by paper birch seeds by over 10 to 1 .

6. Populus. -At Mirror Lake, Populus pollen percentages reached a little over $5 \%$, and influx peaked between 10000 and $9500 \mathrm{yr}$ ago (Figs. 5 and 7). Lost Pond had similar percentages and slightly lower influx values during the same period. Populus values were lower at Lonesome Lake and Carter Notch Pond, and lower still at the high-elevation sites, Deer Lake Bog and Lake of the Clouds, where Populus pollen percentages were never $>\mathbf{2} \%$ during this zone (Spear 1981).

7. Alder.-Peak alder percentages and influx occurred at the following times along the elevational transect (Figs. 5-7): Mirror Lake 10000 yr BP, Lost Pond 10000 yr BP, Lonesome Lake 9500 yr BP, and Carter Notch Pond 9500 yr BP. The pollen record at Little East Pond was not studied in detail, but the record of alder pollen appears to be very similar to Lonesome Lake, the site closest to it in elevation. Only two sites, Lost Pond and Carter Notch Pond, have a macrofossil record of alder. Several seeds were found at Lost Pond, and anthers were found in Carter Notch Pond sediments (Fig. 8A). The record at Carter Notch is particularly intriguing. Here alder pollen percentages and alder macrofossils persisted until the mid-Holocene, similiar to the record reported by Spear (1989) at Kinsman Pond and Eagle Lake Bog, sites only a few hundred metres higher than Carter Notch Pond. The pollen at these sites has been identified as green alder (Alnus crispa).

8. Pine. - It is doubtful that significant numbers of pine trees grew in the White Mountains before 9000 yr BP as pollen percentages were $<20 \%$, a value often found well outside the range of pine trees (Davis and Webb 1975). Most of the pine pollen was small, with diploxylon-type morphology in the Mixed-Conifer Woodland Zone.

9000-7000 yr BP (Pine/Oak Zone). - The pollen assemblages from 9000 to 7000 yr BP were dominated by two pollen types, pine and oak. The beginning of this period is defined by percentages of pine pollen $>20 \%$ and oak $>10 \%$ (Figs. 5-7). The end of the interval is marked by declining percentages of pine and 


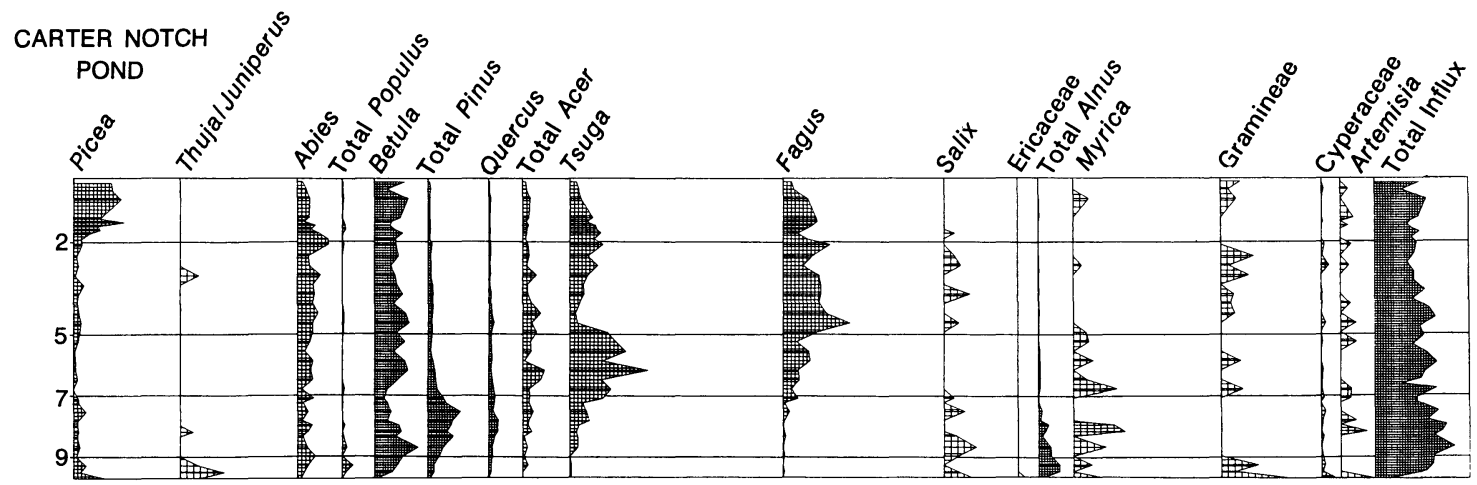

LONESOME LAKE

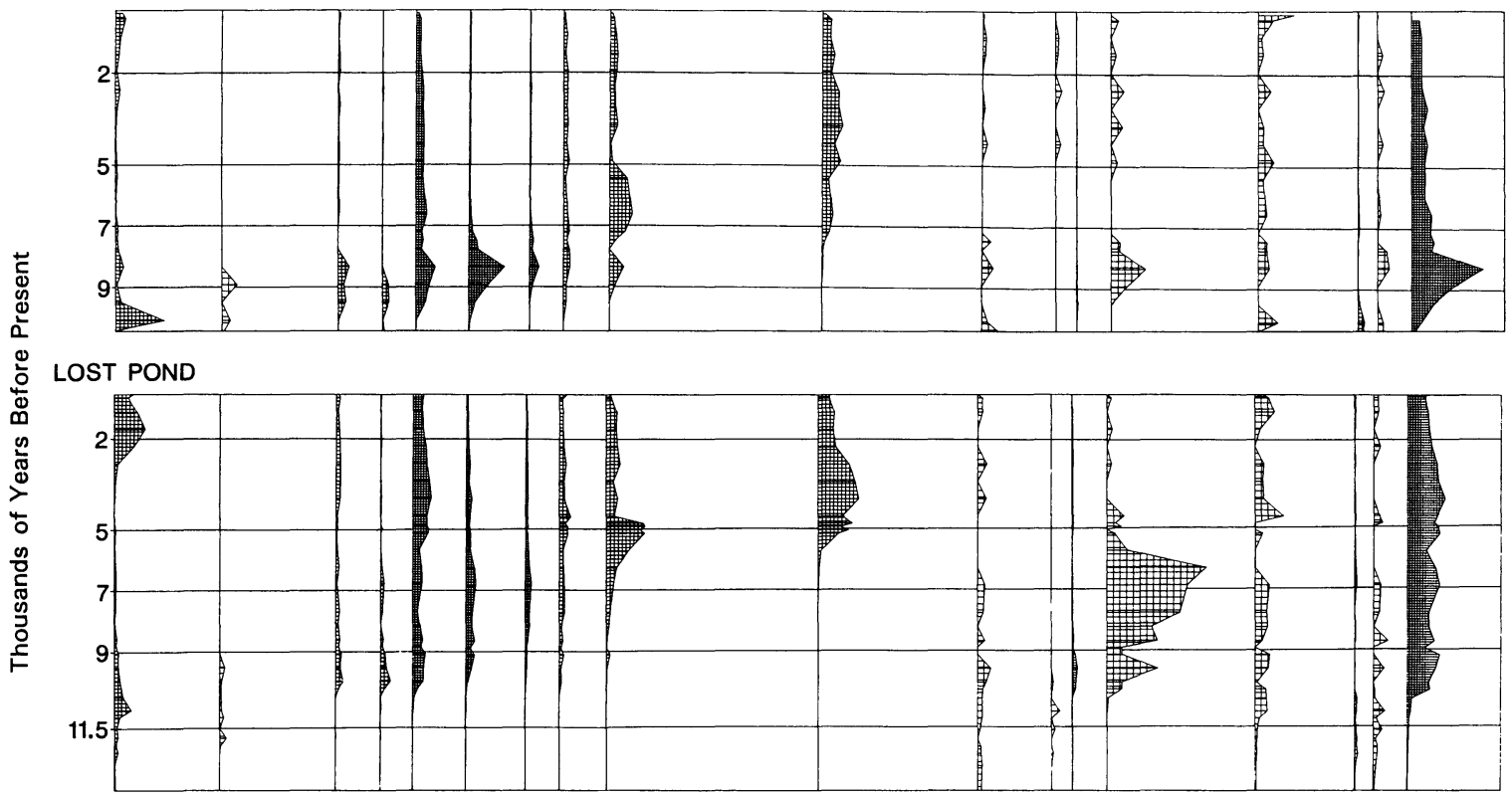

MIRROR LAKE

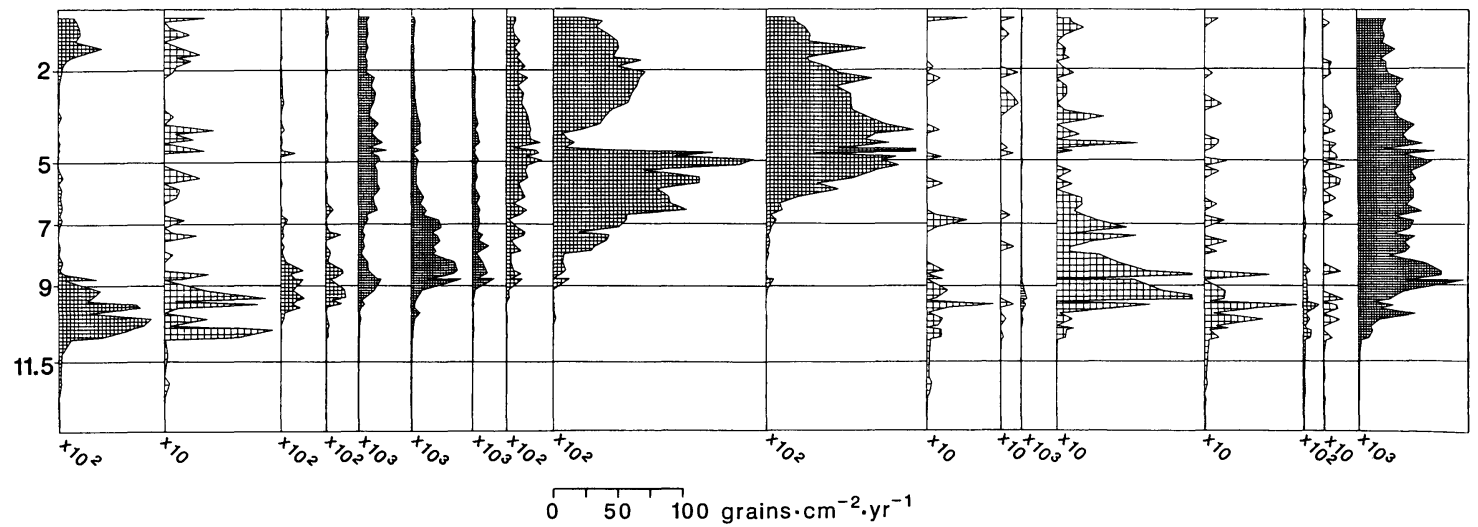

Fig. 7. Pollen influx diagrams in elevational sequence with the lowest coring site at the bottom: Mirror Lake $213 \mathrm{~m}$, Lost Pond $625 \mathrm{~m}$, Lonesome Lake $831 \mathrm{~m}$, and Carter Notch Pond $1004 \mathrm{~m}$.

oak, increasing percentages of hemlock $>10 \%$, and by beech $>1 \%$.

1. Pine.-At Mirror Lake, maximum pine pollen percentages and influx occurred between 8800 and 8300 yr BP (Figs. 5 and 7). Almost all of the needles and most of the pine pollen were from white pine, with the first needles dating to $9900 \mathrm{yr}$ BP (Fig. 8B). Two red pine needles were found in samples dating from 7500 
and 6900 yr BP. At Lost Pond, pine pollen was less abundant than at Mirror Lake. However, percentages and influx at Lost Pond remained relatively high until $5600 \mathrm{yr}$ ago, $>1000 \mathrm{yr}$ longer than at Mirror Lake. White pine needles were abundant $7300-4000 \mathrm{yr}$ ago (Figs. 6-8). At Little East Pond, very low numbers of white pine needles occurred throughout the Holocene, while at Lonesome Lake, needle fragments occurred only at 6000 yr BP (Fig. 8b). Pine pollen at Lonesome and Carter Notch was intermediate in abundance between Mirror and Lost Pond (Figs. 6 and 7).

2. Oak. - Oak pollen representation varied less along the elevation transect than pine. Mirror Lake had peak oak percentages and influx values $8000 \mathrm{yr}$ ago, as did the mid-elevation sites. Maximum oak influx at Carter Notch was much less than at Mirror Lake (Figs. 5-7), although total pollen influx was similar at the two lakes.

3. Birch. - Birch pollen percentages and influx and birch macrofossils were higher from 9000 to $7000 \mathrm{yr}$ BP at all of the sites above Mirror Lake than at Mirror Lake itself. For example, at $\approx 8000 \mathrm{yr} \mathrm{BP}$, birch pollen percentages and influx were $\approx 25 \%$ and $\approx 3500$ grains $\cdot \mathrm{cm}^{-2} \cdot \mathrm{yr}^{-1}$ at Lost Pond and $\approx 10 \%$ and $\approx 2000$ grains $\cdot \mathrm{cm}^{-2} \cdot \mathrm{yr}^{-1}$ at Mirror Lake (Figs. 5-7). The difference in influx is significant as total pollen influx is typically 2 times higher at Mirror Lake than at Lost Pond. Paper birch seeds were also more abundant at mid-elevation sites than they were at Mirror Lake.

4. Sugar maple. -Sugar maple pollen reached values $>0.5 \%$ at all sites by $9000 \mathrm{yr}$ BP. Because maple pollen is poorly represented in the pollen record (Davis and Webb 1975), even these low percentages may mean its populations had spread onto the mid-elevation slopes above Mirror Lake at this time. One sugar maple leaf was found in Lost Pond sediments dating from 7900 yr BP.

5. Spruce and fir.-Spruce and fir pollen occurred at low frequencies $(<3 \%)$ at all sites. Continuous occurrences of macrofossils of spruce and fir at the sites above Mirror Lake suggest that both species were present in the vegetation up to tree line from 9000 to 7000 yr BP. Fir needle fragments were abundant at Carter Notch Pond, where pollen percentages were $2-3 \%$.

6. Larch. - At Lonesome Lake larch was the most abundant conifer needle in sediments of this age. Larix pollen was also present in the pollen record.

7. Hemlock. - At Mirror Lake a few fragments of hemlock needles occurred in sediments dating from 9000 yr BP; however, large numbers and continuous representation of needles did not begin until $7500 \mathrm{yr}$ ago (Fig. 8B). The record at Lost Pond was similar to Mirror Lake, except that hemlock needles first occurred 2000 yr later ( $7000 \mathrm{yr}$ BP) and were fewer in number. A few fragments of hemlock needles were also found in sediments at Little East Pond, Lonesome Lake, and Carter Notch Pond.

8. Yew.-Taxus needles were found at two sites, Lost Pond and Carter Notch Pond. Scattered occur- rences of yew pollen in early Holocene sediments at Lost Pond correspond fairly well with the occurrence of a needle at $8400 \mathrm{yr}$ BP. At Carter Notch, yew pollen predated the first occurrence of needles $7100 \mathrm{yr}$ ago.

7000 yr BP to present (Hemlock/Hardwood Forest Zone). - This zone is divided into three subzones based on the pollen records of hemlock, beech, and birch. (1) Hemlock pollen percentages $>10 \%$ and beech pollen percentages $>1 \%$ at $7000 \mathrm{yr}$ BP initiate the first subzone, which is dominated by these two pollen taxa plus birch pollen. (2) The lower boundary of the second subzone is marked by a precipitous fall in hemlock percentages $4850 \mathrm{yr} \mathrm{BP}$, a feature extensively discussed by Davis $(1981 a, 1983,1985)$ and Allison et al. (1986). Hemlock pollen percentages slowly recovered, starting at $4000 \mathrm{yr} \mathrm{BP}$ and returned to previous values by 3000 yr BP. (3) A rise in spruce pollen marked the beginning of a third subzone $2000 \mathrm{yr}$ BP to present.

1. Hemlock. - At Mirror Lake hemlock pollen percentages rose above $10 \% 7400 \mathrm{yr}$ ago, reaching levels of $30 \%$ several times and peaking at $\approx 34 \%$ around $4850 \mathrm{yr}$ ago. Maximum influx of 15000 grains $\cdot \mathrm{cm}^{-2} \cdot \mathrm{yr}^{-1}$ occurred during this interval. By $\approx 4200 \mathrm{yr} \mathrm{BP}$, percentage and influx values had dropped to a minimum of $\approx 2.0 \%$ and 670 grains $\cdot \mathrm{cm}^{-2} \cdot \mathrm{yr}^{-1}$. The values slowly increased, reaching $29 \%$ and 6600 grains $\cdot \mathrm{cm}^{-2} \cdot \mathrm{yr}^{-1}$ by $1725 \mathrm{yr}$ ago (Figs. 5 and 7). At this time focusing was less intense (Davis et al. 1984, 1985) and influx values were consistently lower than during the early and middle Holocene. From $6800 \mathrm{yr}$ BP until $4850 \mathrm{yr}$ BP an average of 300 hemlock needles per level were found (Fig. 8B). The hemlock decline could not be seen clearly in the macrofossil record.

At elevations above Mirror Lake, hemlock pollen was less than half as abundant, and macrofossil numbers were an order of magnitude smaller. At Lost Pond, hemlock pollen percentages rose above $10 \%$ over 1000 yr later than at Mirror Lake, reaching a maximum percentage of hemlock pollen (14.3\%) and influx (and hemlock needles) just prior to the decline. Hemlock never regained the percentage and influx values that it had before the hemlock decline, reaching only $5.6 \%$ or 810 grains $\cdot \mathrm{cm}^{-2} \cdot \mathrm{yr}^{-1}$ by $1100 \mathrm{yr}$ ago (Figs. 6,7 , and $8 \mathrm{~B})$. Pollen percentages at higher sites are similar to Lost Pond, except that they rise above $10 \%$ earlier (7000 yr BP), perhaps because pollen was blown upward from lower elevations. Hemlock needles were found in sediments dating from 6000 to $7000 \mathrm{yr}$ ago at Little East Pond but were more abundant and continuous at Lonesome Lake. Carter Notch Pond also had continuous low levels of hemlock needles from 7100 to 4750 yr BP (Fig. 8B).

2. Beech. -The pollen profiles for beech show the same altitudinal trends as hemlock. Beech pollen percentages at Mirror Lake rose above $1 \%$ by 7000 yr BP, reaching $13 \% \approx 6000 \mathrm{yr} \mathrm{BP}$ and $20 \%$ by $\approx 5000 \mathrm{yr} \mathrm{BP}$. Pollen percentage and influx values peaked $4700 \mathrm{yr}$ BP $\left(\approx 33 \%, 1900\right.$ grains $\left.\cdot \mathrm{cm}^{-2} \cdot \mathrm{yr}^{-1}\right)$. At Lost Pond, beech 


\section{Abies balsamea}

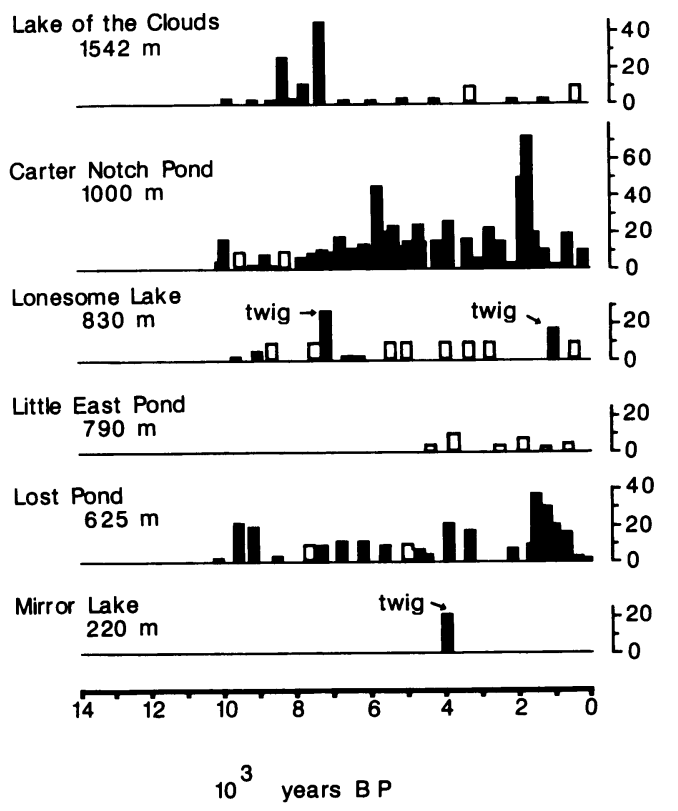

Picea

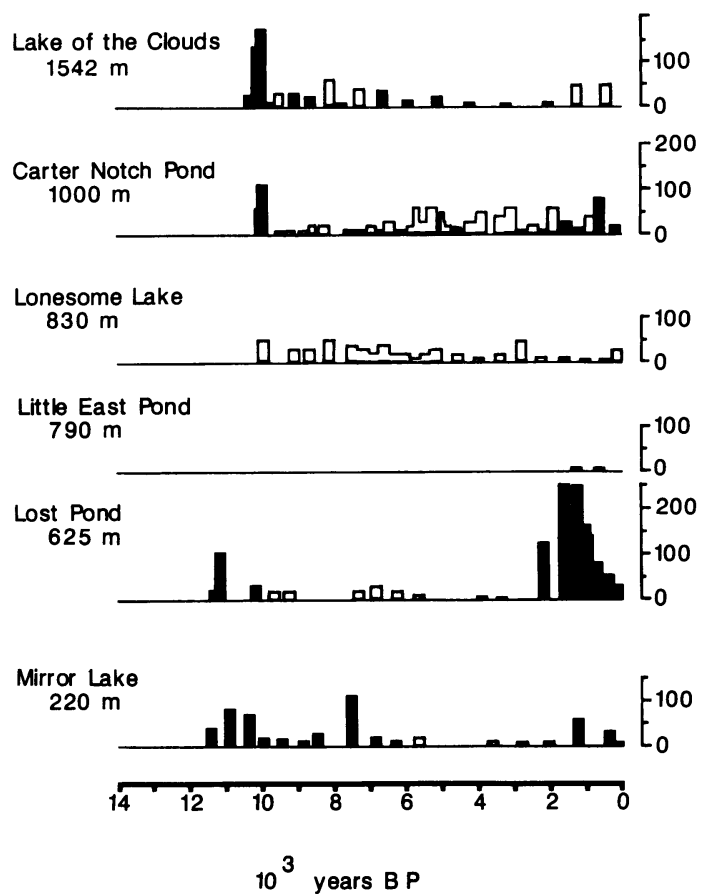

\section{Larix laricina}

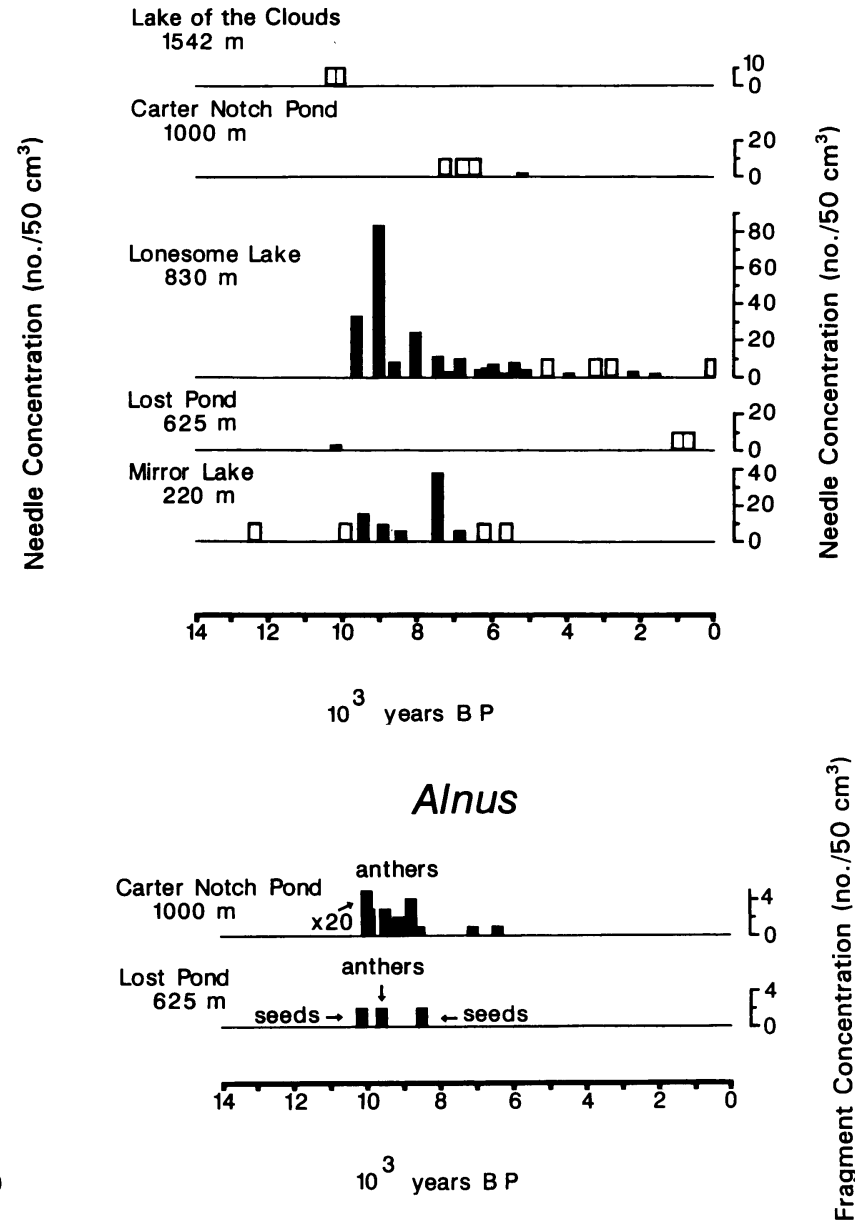

\section{Betula papyrifera}

FIG. 8A. Taxa of spruce/fir forests. Macrofossil diagrams grouped by taxon and stacked in elevational sequence with the lowest coring site at the bottom. Concentrations of needles represent the minimum needle concentrations.
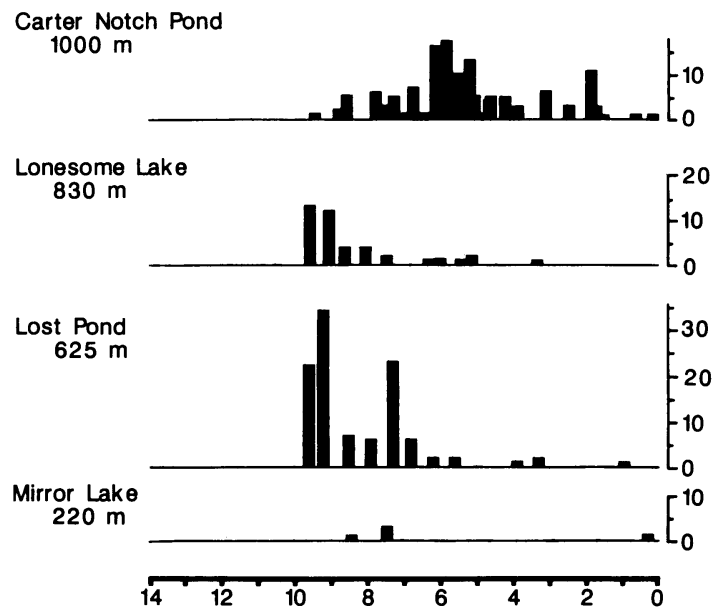

$10^{3}$ years $B P$ 
Pinus strobus

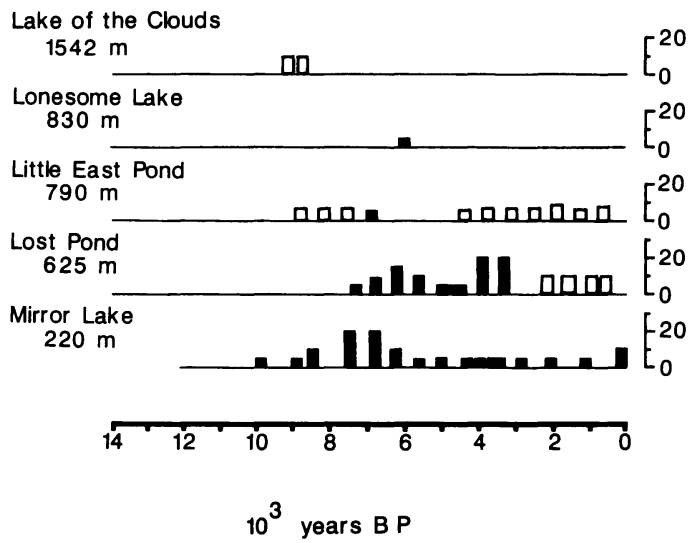

\section{Tsuga canadensis}

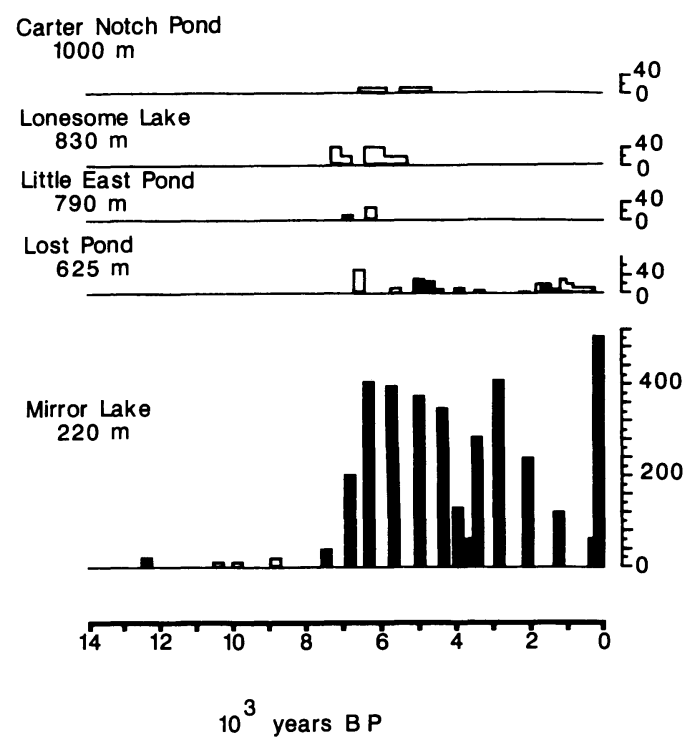

FIG. 8B. Taxa of northern hardwood forests.

pollen increased later, reaching $\approx 2 \%$ around $5700 \mathrm{yr}$ BP; maximum percentage and influx values were much lower than at Mirror Lake. At higher sites beech pollen stratigraphy paralleled Mirror Lake, but with lower percentages and influx values. At Carter Notch Pond, peak influx was only one-third as high as at Mirror Lake (Figs. 5-7). No beech macrofossils were found.

3. Spruce.-Spruce pollen grains occurred only sporadically in Mirror Lake sediments before $3200 \mathrm{yr} \mathrm{BP,}$ rising above $1 \% 2100 \mathrm{yr}$ ago, reaching $11.5 \% 1300 \mathrm{yr}$ ago, and averaging $7.4 \%$ for the remainder of the period. Influx values paralleled this trend. Spruce macrofossils were also found continuously after $3500 \mathrm{yr}$ BP. At Lost Pond spruce pollen was found continuously after $\approx 4000$ yr BP. At Lost Pond macrofossils occurred
Taxus canadensis

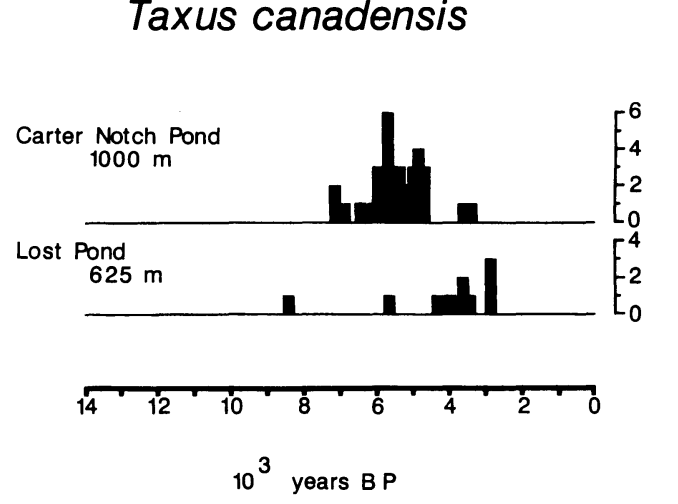

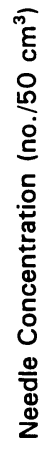

\section{Betula lutea/lenta}
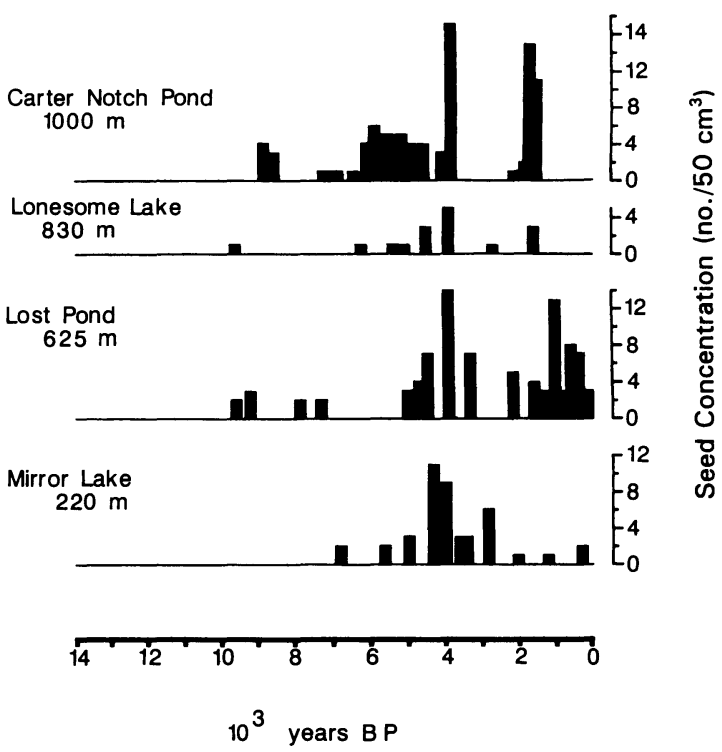

sporadically until $2200 \mathrm{yr}$ BP, with peak numbers of needles between 1500 and 1250 yr ago (Fig. 8A). At Carter Notch Pond, spruce pollen percentages were continuously above $1 \%$ after 5000 yr BP, increasing after 2000 yr BP (Figs. 6 and 7). Needles increased starting 1500 yr BP.

4. Birch.-Birch percentages averaged $\approx 30 \%$ at Mirror Lake. A few scattered paper birch seeds were found in the sediments, but $\mathrm{y} / \mathrm{s}$ birch seeds were much more common. A few y/s birch seeds were found in 7000 -yr-old sediments, with peak numbers in 4300 and 4000-yr-old sediments. High numbers of $y / s$ birch at that time could represent successional change in the forest following the hemlock decline.

At Lost Pond birch pollen percentages remained be- 
tween 30 and $40 \%$ until $5000 \mathrm{yr}$ ago, but rose to $50 \%$ between 5000 and $1000 \mathrm{yr} \mathrm{BP}$, and increased to $65 \%$ after 1000 yr BP. Before 7000 yr BP, paper birch seeds were most abundant at Lost Pond, but after that time $\mathrm{y} / \mathrm{s}$ birch seeds became more abundant, reaching maximum numbers after 5000 yr BP (Fig. 8B). At sites above Lost Pond, birch pollen percentages remained relatively constant, averaging $50 \%$. Carter Notch Pond showed the same transition from paper birch to $\mathrm{y} / \mathrm{s}$ seeds at $\approx 6000 \mathrm{yr}$ BP.

5. Fir. - The pollen diagrams showed no dramatic changes in values of Abies during the middle and late Holocene, and fir macrofossils occurred at all elevations throughout the Holocene. Low numbers of needles were found continuously in Lost Pond sediments; possibly the needles were more abundant in the last $1500 \mathrm{yr}$. This pattern was repeated at Lonesome Lake and at Carter Notch Pond. Percentages of fir pollen were higher at Carter Notch than at the lower elevation sites. At 3000 and 2000 yr ago fir pollen percentages and fir influx values reached small peaks (Figs. 6 and 7), and fir macrofossils were also relatively abundant (Fig. 8A).

\section{Discussion}

\section{Vegetation zonation}

Reconstruction of plant communities. - The distinctness of altitudinal vegetation zones has varied considerably over the last 14000 yr. Fig. 9 and the following brief summary give our interpretation of the late-glacial and Holocene plant communities in the White Mountains.

1. 13700-11500 yr BP (Tundra [T] Zone). - The vegetation in the White Mountains during this period was open tundra, though the vegetation assemblage was not necessarily similar to modern tundra. By $\approx 12750$ yr BP it already displayed differentiation along the altitudinal gradient. Shrub tundra grew around the lower elevation sites, Mirror Lake and Lost Pond. Shrubs included willows, ericads (Vaccinium uliginosum), Shepherdia canadensis, Juniperus/Thuja, and dwarf birch. Sedges were the dominant herbaceous vegetation (Fig. 10).

No paleoecological record is available from the midelevation sites. Spear (1989) hypothesized that residual ice might have persisted in Franconia Notch where all three study sites showed delayed sedimentation. An alternative hypothesis is that the slopes from 700 to $1400 \mathrm{~m}$, which are particularly steep, had not yet stabilized, and therefore remained unvegetated.

Sparse vegetation (herb tundra) grew at high elevations. The taxa present, Gramineae, Artemisia, Tubuliflorae, and Caryophyllaceae, are indicators of disturbance. This must have been a period of intense periglacial activity at higher elevations (Spear 1989).

2. 11500-9000 yr BP (Mixed-Conifer Woodland Zone).-From 11500 to $10000 \mathrm{yr}$ BP, White Mountain plant communities were transitional in nature, as woodlands of spruce with juniper and herbs in the understory became established in the valleys to an altitude of at least $625 \mathrm{~m}$. Watts (1979) has suggested that populations of white, then black, and finally red spruce spread northward during the late-glacial. Because we did not find spruce cones in our macrofossil records and did not attempt to identify needle fragments or pollen to species, we are unable to characterize the spruce woodland in more detail. Shrub tundra grew above $1400 \mathrm{~m}$ and was invaded by spruce (probably krummholz) at $10300 \mathrm{yr}$ BP (Spear 1989) (Fig. 9).

The paleoecological records of woodlands show no signs of the Younger Dryas climatic reversal found at sites farther south in New England (Peteet et al. 1990), farther to the northeast in Atlantic Canada (Mott et al. 1986, Wright 1989, Levesque et al. 1993), or farther west in western Ohio and Indiana (Shane 1987). In southern New England (Peteet et al. 1990) and Ohio (Shane 1987) spruce, birch, and other local species replaced thermophilous taxa, such as oak, hophornbeam, and ash. At coastal sites in Canada northeast of the White Mountains, spruce woodlands were replaced by open vegetation between 11000 and $10000 \mathrm{yr}$ ago (Mott et al. 1986, Wright 1989). In the White Mountains, however, the tree line was advancing upslope between 11000 and $10000 \mathrm{yr}$ BP, and at lower elevations spruce pollen influx, although low, remained constant.

Spruce populations declined dramatically at all elevations after 10000 yr BP. Spruce was apparently replaced by fir, larch, poplar, and paper birch. Each species expanded its range in the low-elevation woodland and then spread rapidly upslope. All four taxa were abundant at 10 000-9000 yr BP at low- and midelevation sites, but larch and poplar populations at this time were probably rare above $1000 \mathrm{~m}$. Fir moved upslope first. Its displacement at low and mid-elevations was followed by larch, whose densest population moved upward to Lost Pond at $9000 \mathrm{yr}$ BP and to Lonesome Lake by 8000 yr BP. Pollen percentage and influx data indicate that the "Poplar Woodland" that Davis and Jacobson (1985) believe covered the lateglacial New England landscape did not occur in the mountains. Instead Populus became abundant at the beginning of the Holocene, but only in the valleys and on the lower slopes. Populus was abundant at that time in southern New Hampshire as well (M. B. Davis and T. D. Allison, personal communication). Paper birch was the last to move upslope. It expanded near Mirror Lake 9500 yr BP, slightly later near Lost Pond and Lonesome Lake, and last at Carter Notch Pond where it persisted in abundance until the late Holocene.

Macrofossil evidence from high-elevation sites (Spear 1989) indicated that scattered paper birch populations had reached an altitude of at least $1200 \mathrm{~m}$ by $9500 \mathrm{yr}$ BP. Extensive fir krummholz with spruce was found around Lake of the Clouds at $10000 \mathrm{yr}$ BP, indicating 

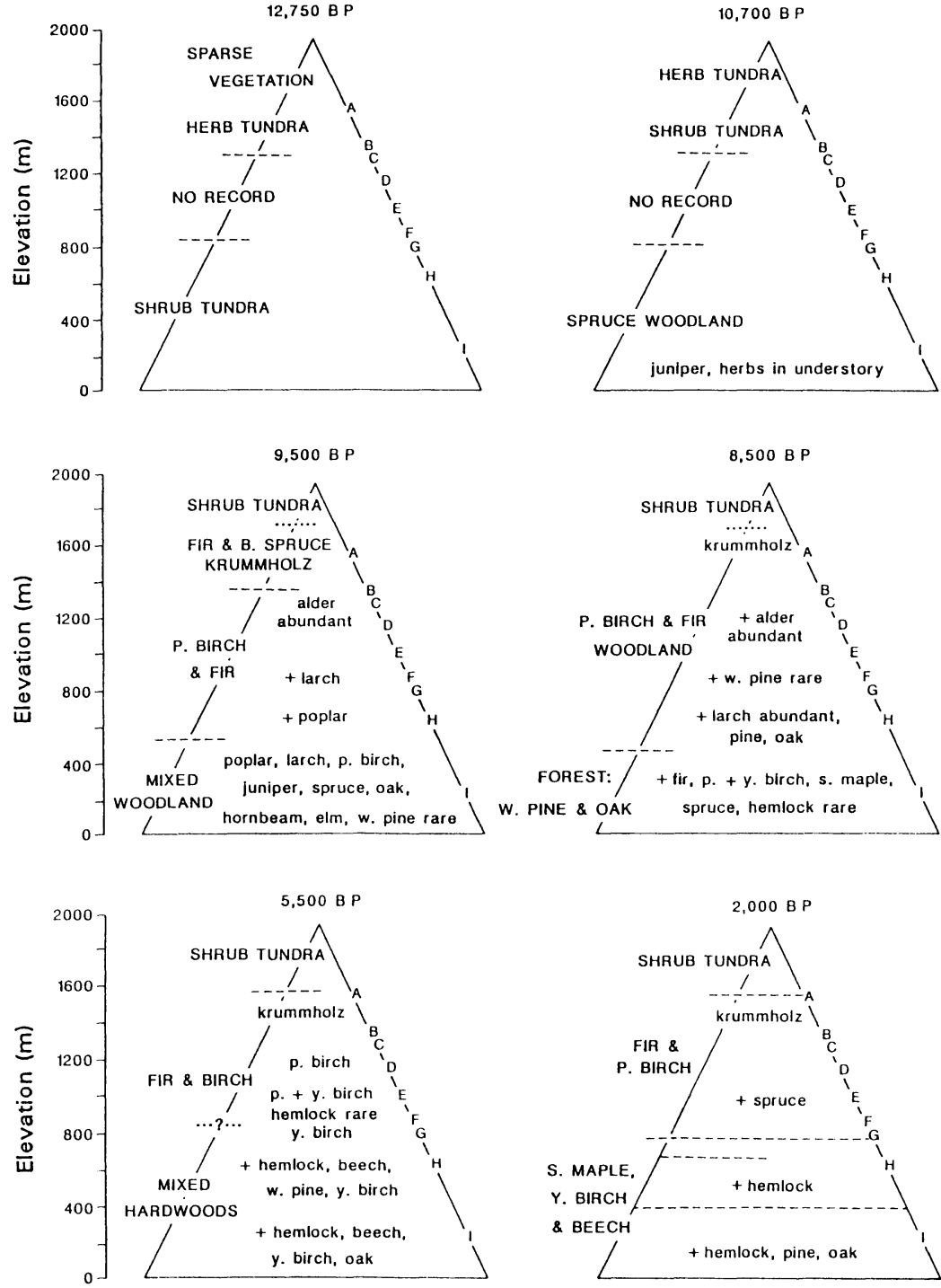

$10,700 \mathrm{BP}$

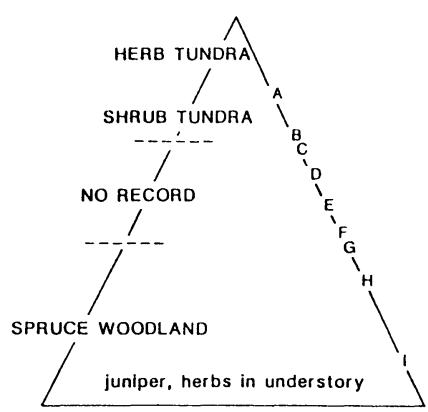

$8,500 \mathrm{BP}$

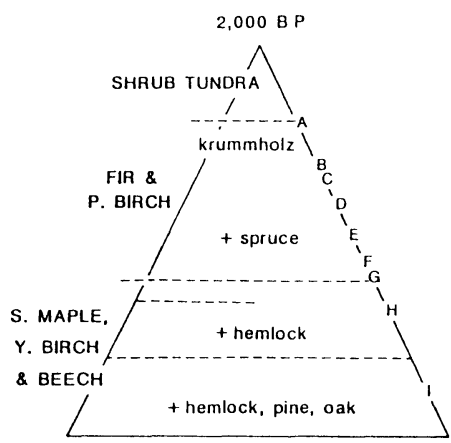

10,000 B P
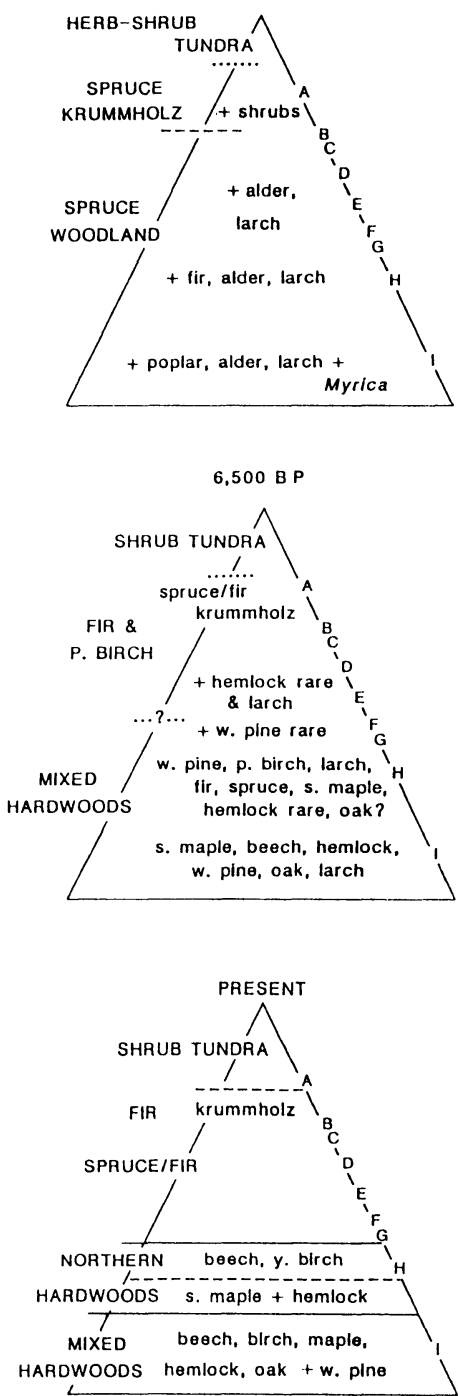

A - Lake of the Clouds B - Deer Lake Bog C - Eagle Lake Bog D - Kinsman Pond E - Carter Notch Pond F - Lonesome Lake G - Little East Pond H - Lost Pond I-Mirror Lake

FIG. 9. Schematic summary of vegetation change through time and across elevational gradients in the White Mountains region of New Hampshire.

that tree line may have been higher than today. During this time, alder and Myrica were common shrubs at low to mid-elevations, although their distribution may have been restricted to lake margins and wetlands.

3. 9000-7000 yr BP (Pine/Oak Zone).-Forests dominated by pine and oak grew at the elevation of Mirror Lake in the early Holocene. The forest also contained a few paper birch and sugar maple, and small numbers of $\mathrm{y} / \mathrm{s}$ birch, spruce, and by $8500 \mathrm{yr} \mathrm{BP}$, hemlock trees. Farther upslope between 600 and $1400 \mathrm{~m}$ open forests of fir and paper birch occurred. Paper birch was especially important in the lower elevation phase of the fir-birch forest. At elevations between 500 and $900 \mathrm{~m}$, the forests included a few pine and oak trees.
At present white pine does not grow above $450 \mathrm{~m}$, except in exceptional microhabitats. The fossil needles suggest it was abundant in the vicinity of Lost Pond during the early Holocene and grew as scattered trees at least as high as Little East Pond (790 m) and possibly as high as Lonesome Lake at $830 \mathrm{~m}$. Larch was also common at mid-elevations, especially around Lonesome Lake. Scattered clumps of yew grew in the midelevation vegetation. Green alder remained an important component of the vegetation between elevations of 1000 and $1300 \mathrm{~m}$ until $6000 \mathrm{yr} \mathrm{BP}$, when it disappeared. Its presence might be related to a combination of climatic factors and the steep slopes at these elevations. Green alder is found near tree line (1500 


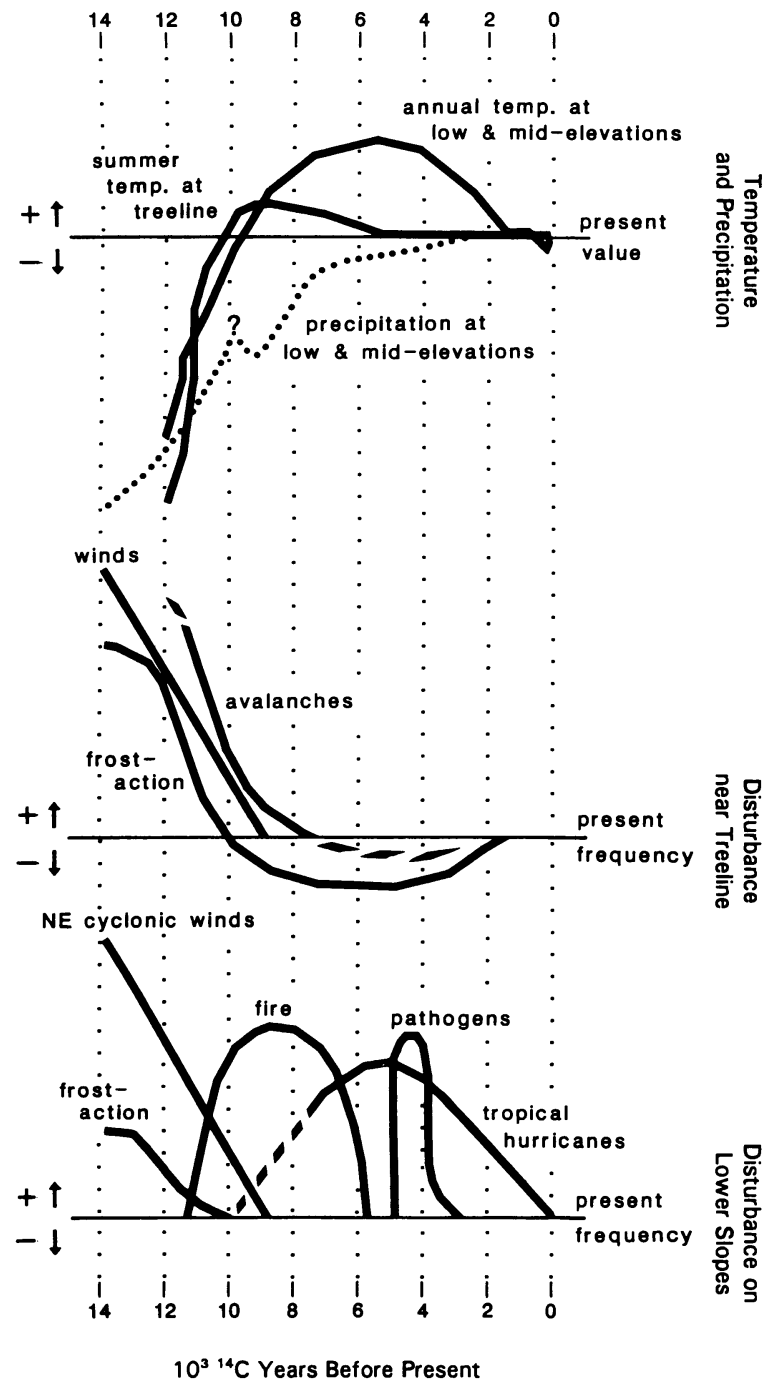

FIG. 10. Schematic summary relating changing climate and changing frequencies in probable and possible disturbance factors in the study area through time to modern conditions.

m) on the east flank of the Presidential Range today. Its distribution is correlated with abundant moisture and high incidence of avalanches.

4. 7000 yr. BP to present (Hemlock/Hardwood Zone).-By 7000 yr BP, mixed-hardwood forest grew around Mirror Lake. Hemlock populations were rapidly expanding and beech populations were becoming established. These species were present in near modern abundance by $6000 \mathrm{yr}$ BP. Subordinate trees in the forest were white pine, oak (probably red oak), and sugar maple. Larch and spruce were present, possibly in poorly drained habitats. The pollen assemblages of this final period resemble those from modern sediments, suggesting that hardwood forests have been present in some form for the last $7000 \mathrm{yr}$.

The dominant taxa are more difficult to determine for elevations above Mirror Lake. A few hundred metres above Mirror Lake, at Lost Pond, populations of white pine and oak (probably red oak) maintained and even expanded their dominance in the forest between 7000 and $5500 \mathrm{yr}$ BP. Sugar maple, paper birch, larch, fir, and spruce trees were also present in low numbers. Hemlock trees were rare. Above Lost Pond, paper birch was a dominant tree in the forest along with larch and fir. Both white pine and hemlock were rare up to elevations of 500 and $1000 \mathrm{~m}$, respectively. Hardwoods with hemlock and beech expanded near Lost Pond ( 650 $\mathrm{m}) \approx 5500 \mathrm{yr}$ BP. The delay (relative to Mirror Lake) in the initiation of their increase at Lost Pond is not merely a local effect; a pollen diagram from Cone Pond (468 m) midway in elevation between Mirror Lake and Lost Pond displays intermediate pollen stratigraphy (Ford 1990).

At 5500 yr BP yellow or sweet (y/s) birch became more prominant in the vegetation at the expense of paper birch, especially at lower and mid-elevations, where birch pollen percentages and seeds increased as a response to the decline in hemlock populations 4800 yr ago. At Carter Notch Pond $(1000 \mathrm{~m})$ and above, paper birch was probably more important in the forests than $\mathrm{y} / \mathrm{s}$ birch. A similar expansion of yellow birch populations occurs in the Adirondack Mountains (Jackson 1989, Jackson and Whitehead 1991). In addition to increases in the altitudinal range limits of white pine and hemlock in both the White Mountains (Davis et al. 1980) and the Adirondacks, Jackson (1989) reports a $150 \mathrm{~m}$ upward displacement of yellow birch populations during the Holocene.

On the slopes above Lost Pond $(625 \mathrm{~m})$ hemlock populations remained low; forests were dominated by birch and fir. After the hemlock decline, hemlock disappeared at sites above $625 \mathrm{~m}$, and at Lost Pond itself hemlock never fully recovered.

Tree line probably moved down to its current elevation sometime after $5000 \mathrm{yr}$ BP (Spear 1989). Expansion of spruce populations occurred synchronously $2000 \mathrm{yr}$ ago at elevations below $1200 \mathrm{~m}$. Regional spruce expansion followed a different pattern moving southward from eastern Canada over the past several thousand years (Webb et al. 1983, Gaudreau and Webb 1985, Webb 1986). Apparently tree line krummholz and subalpine fir were the only plant communities in which spruce failed to expand (Spear 1989). It was at this time that plant communities indistinguishable from modern ones became established. However, adjustment of white pine and hemlock altitudinal limits to their present values seems to have occurred as recently as $300 \mathrm{yr}$ ago, during the Little Ice Age (Davis et al. 1980).

\section{CONCLUSIONS}

There are at least two stages to the interpretation of paleoecological data sets. First is building a picture of the history of change in the communities being studied; 
what taxa were present or absent in what frequencies at what times. Second is attempting to understand the causes of the changes observed.

\section{Community continuity and changes}

The plant communities of the White Mountains have undergone continual change over the past $14000 \mathrm{yr}$. Similar change is reported by Jackson (1989) and Jackson and Whitehead (1991) in the plant communities of the Adirondack Mountains. Each modern vegetation zone on the mountain slopes reflects a functional response to interspecies interactions and to exogenous forces rather than a long evolutionary history during which selection has facilitated partitioning of resources.

The earliest post-Wisconsinan hardwood forest became established $5000 \mathrm{yr}$ after ice retreat, $\approx 9000 \mathrm{yr}$ ago. The assemblage, rich in oak and pine, was different from any modern forest communities in the region. Hemlock, beech, and maple then colonized the area $7000 \mathrm{yr}$ ago, and the resemblance to modern forests increased. Major changes in abundances of the dominant trees occurred again 5000-3000 yr ago during the decline and reestablishment of hemlock. Spruce (probably red spruce) was virtually absent until as recently as $\approx 2000 \mathrm{yr}$ BP. Additional adjustments in elevation limits of conifers such as pine and hemlock have been continuous since 7000 BP to the Little Ice Age (14501850 AD). Logging at the turn of the century probably removed the last relicts that remained from the previously more extensive distributions of these species. In the modern successional forests, hemlock, beech, and red spruce are less abundant than in pre-European settlement time, while birch (white and yellow), red maple, and aspen are all more abundant.

The spruce-fir forests, now so characteristic of elevations between 750 and $1200 \mathrm{~m}$, had a very different pattern. The modern spruce-fir forests developed only during the last $2000 \mathrm{yr}$ when spruce populations increased. Up until then the subalpine forests bore little resemblance to the Canadian boreal forest where spruce is a key species. During late-glacial time $11000-9000$ yr ago, the distributions of spruce and fir were quite different from one another, and spruce was very much more abundant than fir. About $10000 \mathrm{yr}$ ago as spruce populations declined, fir became abundant and formed a woodland at low elevations. Fir woodland moved quickly upslope to tree line at $\approx 1400 \mathrm{~m}$ where it persists today (Spear 1989). Between 9000 and $2000 \mathrm{yr}$ BP there was no vegetation assemblage equivalent to the modern spruce-fir forest.

Continuity of the tundra community is difficult to evaluate because we have so little detailed information on species composition. The record we have shows that tundra species grew even at low elevations over 10000 yr ago, but apparently persisted only above tree line after that time. Spruce had replaced tundra at the location of modern tree line by 10300 BP. By 9700 yr
BP, fir krummholz extended higher on the slopes than today, and it persisted there until $\approx 5000 \mathrm{yr}$ ago (Spear 1989). During this time the species composition of the tundra vegetation changed; Dryas, for example, was lost from the flora.

\section{Equilibria of plant distributions with climate}

The elevation of transect or sites was chosen because nearby sites spanning a steep environmental gradient eliminate the problem of seed source as a cause for migration lag. Progressive establishment beginning at low elevations is evidence for range extension in response to (and in equilibrium with) gradual warming. The only clear evidence of such movement in the data set is the time-transgressive establishment of pine, oak, hemlock, and beech upslope at the two low-elevation sites. Both pollen and macrofossils of hemlock appear significantly earlier at Mirror Lake than at Lost Pond, and peak abundances for pollen of all four species are attained later at Lost Pond than at Mirror. Most of the sites above Lost Pond contain sufficient macrofossils of warmth-demanding species to indicate presence but not to establish arrival time. Consequently, as discussed below we interpret our results to provide a record of large-scale community change related without time lags to major climatic and other long-term perturbations.

\section{Environmental factors}

Soils. - During the first two millennia following deglaciation, frost action and mass wasting occurred even at low elevations, and massive frost features and landslides were formed near the mountain summits (Goldthwait 1940, 1970, 1976). Silt was probably blown from barren mountain peaks and from the floodplains in the valley. Slopes were unstable and incipient soil profiles were disrupted (Fig. 10).

Sediment stratigraphy and loss-on-ignition data indicate silt deposition at all elevations prior to 10000 yr BP. At Mirror Lake inputs of silt declined earliest, beginning at $11500 \mathrm{yr} \mathrm{BP}$, as spruce woodland became established on the watershed. A similar change occurred later at Lost Pond when woodland developed $\approx 11000 \mathrm{yr}$ BP (Spear 1981). The change from organic to inorganic sediments characteristic of the Younger Dryas in Nova Scotia and New Brunswick (Mott et al. 1986, Levesque et al. 1993) is not found at our White Mountain sites. At sites between 800 and 1400 m (midelevations) (Lonesome Lake, Kinsman Pond, and Eagle Lake Bog), deposition of unfossiliferous inorganic sediment stopped abruptly at $10000 \mathrm{yr}$ BP, indicating that the steep slopes at mid-elevations stabilized at this date. A very large landslide had occurred just prior to 10000 yr BP, forming Carter Notch Pond. At higher elevations (Lake of the Clouds), inorganic inputs decreased slightly $10000 \mathrm{yr} \mathrm{BP}$, but they have always remained high, consistent with the independent fossil 
evidence that trees have never become established there (Spear 1989).

Paleolimnological studies at Mirror Lake have traced a 14000 -yr history of the lake's watershed (Davis et al. 1985). Diatoms in lake sediments suggest neutral to slightly alkaline lake water during the late-glacial. The presence of Dryas integrifolia in the macrofossil record also suggests neutral soil conditions. Dryas no longer occurs in the White Mountains, even above tree line, presumably because weathering and leaching have lowered soil $\mathrm{pH}$. White spruce may also have grown in the White Mountains during late-glacial time. Although we have not made species identifications of pollen or needles, fossils from this species have been identified from late-glacial deposits in the Adirondacks (Jackson 1989). White spruce does not grow in the White Mountains now, although it occurs at similar latitude and elevations in the Green Mountains of Vermont, where soils are calcareous. Although these species suggest neutral soil conditions, the presence of ericads in late-glacial time suggests that neutral soils did not persist for long; humus probably began to accumulate in protected sites even during the late-glacial (Miller and Thompson 1979, Davis 1983, Davis et al. 1985).

After 10000 yr BP, many shade-intolerant tree species, such as aspen, paper birch, larch, fir, and hornbeam grew in what was apparently an open woodland. All of these species can become established on bare mineral soil. On more mesic sites soil development may have proceeded more rapidly, and sugar maple and elm became established. Elsewhere, on poorer soil, white pine and oak increased in abundance, first at lowest elevations, and subsequently near Lost Pond. Gradually increasing lake productivity from 10000 to $6000 \mathrm{yr}$ BP at Mirror Lake indicates that several millennia passed before the area surrounding the lake developed mature soil profiles (Davis et al. 1985). Because hardwood forests like those at Mirror Lake developed slightly later (6000 yr BP) at Lost Pond, we presume that development of mature soil profiles at Lost Pond was also later. Ford (1990) gives a detailed record of soil development and ecosystem acidification at Cone Pond ( $473 \mathrm{~m}$ ) (a site $15 \mathrm{~km}$ from Mirror Lake). Here both the expansion of hemlock $\approx 7000 \mathrm{yr} \mathrm{BP}$ and spruce $\approx 2000$ yr BP had a strong effect on soil development. Presumably at our sites below $650 \mathrm{~m}$, especially those with thin soils and steep slopes, the increased abundances of both hemlock and beech after $6000 \mathrm{yr}$ BP led to increased podsolization of the forest soils. This trend was undoubtedly augmented by spruce expansion $2000 \mathrm{yr}$ BP as it began to grow mixed with hardwoods below $750 \mathrm{~m}$, and with fir above $750 \mathrm{~m}$.

Disturbance. - The intensity and frequency of disturbance such as fire, pathogens, and wind have not been uniform during the $14000 \mathrm{yr}$ of history in the White Mountains.

1. Fire. - The frequency of fires is evidenced by the rate of charcoal accumulation in Mirror Lake, which was several times higher between 11000 and $7000 \mathrm{yr}$ $\mathrm{BP}$ than in recent millennia, reaching highest rates in sediments deposited between 9000 and 7000 yr BP (Davis 1985) (Fig. 10). Macrofossil evidence at sites above Mirror Lake also indicates higher numbers of charred plant material (Spear 1981). Anderson et al. (1986) report high levels of charcoal in sediments from South Branch Pond, Maine from 9800 to 7500 yr BP. Milankovitch theory indicates that summer insolation was at a maximum during this period, perhaps resulting in hot, dry summers that promoted fires (Berger 1978, Kutzbach and Guetter 1986, COHMAP 1988). Between 11000 and 7000 yr BP the woodland surrounding Mirror Lake and other low-elevation sites was primarily coniferous, and therefore more fire-prone than the hardwood forest of the late Holocene. Deciduous trees that were common between 9000 and 7000 yr BP such as paper birch and poplar commonly occur as successional species following fires. White pine and oak also grow in regions where fires are common. Firesensitive species, such as hemlock and beech, either did not occur at all or were uncommon until after 7000 yr BP. The historical record suggests that there have been only infrequent fires in recent millennia in central New Hampshire and Maine (Bormann et al. 1985, Anderson et al. 1986).

It is noteworthy that jack pine (Pinus banksiana), a species with resinous cones that open following fires, was rare in New Hampshire during the period when fires are supposed to have been most common, although the tree was common in Massachusetts between 10000 and 9000 yr BP (Davis 1958, Davis and Jacobson 1985). In New Hampshire white pine invaded aspen woodland directly without an intervening jack pine phase. It is possible that jack pine was uncommon because fires were of limited extent due to the rugged topography. Jack pine does grow today on south-facing bedrock ledges only $10 \mathrm{~km}$ from Mirror Lake.

2. Pathogens. - At low and mid-elevations $4850 \mathrm{yr}$ BP, hemlock, a dominant species in the forest, suddenly declined in abundance, apparently because of a pathogen outbreak (Davis 1981a, 1983, Allison et al. 1986, Anderson et al. 1986). This had a major impact on the forests, causing large-scale increases in successional trees that replaced the hemlock. On higher slopes hemlock populations disappeared at the time of the decline and never recolonized. By $3000 \mathrm{yr}$ BP the forest near Mirror Lake had "recovered"; pollen assemblages were nearly indistinguishable from those $2000 \mathrm{yr}$ earlier, prior to the decline.

3. Wind.-Our data provide indirect evidence of changing wind intensities over the past $14000 \mathrm{yr}$. Wind currently affects the White Mountain vegetation in two principal ways: through control of tree line and through periodic blowdowns in conifer and hardwood forests. The latter are caused by strong winds from frontal storms and thunderstorms and tropical hurricanes 
(Bormann et al. 1985). Prior to $10000 \mathrm{yr}$ BP, the whole region was probably swept by intense, cold, dry anticyclonic winds generated by the high-pressure system over the retreating ice sheet (COHMAP 1988). As the glacial anticyclones dissipated $9000 \mathrm{yr}$ BP, the westerlies as well as air movement from the south became important. Presumably these conditions have persisted through the remainder of the Holocene. The strong winds that characterize the high peaks today result from the orientation of the prevailing westerlies perpendicular to the long axis of the Presidential Mountain massif. For this reason, there has been little change throughout the Holocene in the position of tree line, even though the upper limits of low-elevation taxa have changed as much as $300 \mathrm{~m}$.

Because increased northward penetration of tropical air masses associated with meridional patterns of weather movement (Bryson 1966) favor the northward movement of hurricanes, one might expect a positive correlation between hurricane frequency and the warmer temperatures at low and mid-elevations 7000$4000 \mathrm{yr} \mathrm{BP}$. The warmer temperatures during this time should have intensified and strengthened hurricanes (Emanuel 1987, Overpeck et al. 1990). Overpeck et al. (1990) also report that General Circulation Models predict that higher temperatures result in stronger and more frequent thunderstorms. The mid-Holocene, when low-elevation taxa moved upslope and grew more abundantly, might have been a time when frequent catastrophic storms favored paper birch and fir over spruce (Davis and Botkin 1985).

Temperature and moisture.-Forests at lower elevations were apparently affected by a complicated set of climatic variables. These resulted from changes in prevailing air masses controlled by the pattern of general atmospheric circulation (Bryson 1966). Summer storms that bring precipitation to the White Mountain region often have their origin over the Atlantic. In general, these Atlantic air masses are warmer than the dry air masses originating from Canada. Warm dry air can move to the New England area from the midcontinent in summer, and the same source can bring cold dry air in winter. Storms along the southern margin of such continental high-pressure cells are frequent sources of rain in the summer or snow in winter. Past changes in the prevalence of air masses reaching the mountains would have changed not only the temperature and the amount and timing of precipitation, but also the lapse rate, because stability and moisture content affect the rate of cooling of air that rises over the mountain mass (Webster and Streten 1978). For this reason, climatic changes observed at one elevation need not equal changes at another.

The gradient of temperature change with elevation was apparently steepened in the past, as evidenced by changes in altitudinal limits of low-elevation species ( $300 \mathrm{~m}$ for white pine and hemlock) that far exceed the changes in the position of tree line $(\approx 50 \mathrm{~m})$.
The absence of evidence for climatic oscillation associated with the Younger Dryas event 10 000-11 000 yr BP may reflect an insensitivity of all the White Mountain vegetation (lack of indicator species) to the cooling event. Shane (1987) believes the western Ohio and Indiana sites whose records reflect this climatic oscillation were on an ecotone between boreal (spruce) and deciduous forests. In New Hampshire we would expect to see a fluctuation in the forest/tundra ecotone. Pollen response surface data (Prentice et al. 1991) suggest that samples with $10-30 \%$ sedge and $\approx 20 \%$ spruce pollen (such as found in the lower levels of Mirror Lake) are deposited in environments with low precipitation (under $500 \mathrm{~mm}$ per year) and variable temperatures (July temperatures of $9^{\circ}-15^{\circ} \mathrm{C}$, January temperatures of $0^{\circ}$ to $-30^{\circ} \mathrm{C}$. Consequently, precipitation level rather than temperature was probably critical in determining the ecotone boundary between spruce woodland and tundra (tree line) at low elevations in New Hampshire 11500 yr ago. During Younger Dryas time climatic cooling of only a few degrees Celsius would have had little effect on the spruce woodlands at low elevations. Tree line was found higher on the mountain slopes at mid-elevations. Perhaps the fact that the slopes around our mid-elevation sites were highly unstable and sedimentation did not begin at these sites until $10300 \mathrm{yr}$ BP indicates that climatic conditions were still severe and the late-glacial did not experience progressive climatic warming. Alternatively, the dominant influence of continental air masses and air circulation determined by the waning Laurentide Ice Sheet may mean the White Mountains never experienced this climatic oscillation.

The history of spruce does suggest, however, that a major warming occurred $10000 \mathrm{yr}$ ago, when spruce declined at all elevations except near modern tree line, where it increased until 9500 yr BP, declining thereafter. We suggest that a sharp increase in temperature occurred at $10000 \mathrm{yr}$ BP that made conditions too warm for spruce at all elevations except near tree line, where it increased. The change may be related to the retreat of continental ice to a position north of the St. Lawrence River. The White Mountains could then have been outside the range of winds produced by the highpressure cell over the ice sheet. Later influences on spruce are more problematic: after 8500 yr BP conditions were unfavorable for spruce even at tree line. Spruce grew sparsely near several of the sites on the elevation transect during the subsequent $5000 \mathrm{yr}$ (as evidenced by marcofossils), but it was rare regionally; its pollen occurred in smaller amounts at all of our fossil sites than in any surface samples from any elevations in the White Mountains. Conditions changed between 3000 and 1000 yr BP, causing spruce (probably red spruce) to increase at low and mid-elevations. Unlike the Adirondacks (Jackson and Whitehead 1991), the increase in spruce does not start at mid-elevations and move downward, as would be expected with pro- 
gressive cooling, but instead occurs simultaneously, suggesting that a threshold was exceeded at all elevations in the White Mountains. The nature of the control is not understood, but might have involved more soil moisture or cooler summers, combined with conditions at high elevations that continued to discourage the growth of spruce, such as heavy snowfall and a high rate of disturbance (Sprugel 1976, Sprugel and Bormann 1981).

The sharp decline of spruce $10000 \mathrm{yr} \mathrm{BP}$ and the replacement of spruce woodland by early successional trees capable of growing on dry, nitrogen-poor soils, such as aspen, paper birch, fir, and larch, fit with an interpretation of a continuation and even intensification of dry, continental conditions with high summer insolation common in the late-glacial (Rind et al. 1986). Fires were common. If winters were cool, without heavy snowfall, soils would have frozen deeply. During the cold and sunny winters, conifers other than pine, which has a taproot, might have suffered from moisture stress, as they do today along the prairie border and in some arctic regions (Garfinkel and Brubaker 1980). In New Hampshire today soils remain unfrozen under a deep snow cover (Likens et al. 1977), and then become completely saturated with moisture at the time of snow melt. The reservoir of soil moisture is only partly used during the summer months so trees do not suffer moisture stress (Likens et al. 1977). If the ground froze as the result of low winter temperatures during the early Holocene, moisture from melting snow would have been lost as run-off. Without soil moisture replenishment from snowmelt, early Holocene soils might have become extremely dry during the hot summer months, causing stress for many trees.

These conditions may explain the rapid displacement upslope of fir, which grew briefly in the vicinity of Mirror Lake immediately after the spruce decline, then became abundant near Lost Pond, and then near Carter and finally at tree line. Fir persisted at high elevations throughout the Holocene. At low elevations, it grew only in particular microhabitats, for example, adjacent to Lost Pond where it grows today. Alder also expanded briefly $10000 \mathrm{yr}$ BP, retreating upslope rapidly and becoming rare after $8500 \mathrm{yr}$ BP except in the eastern slopes of the Presidential massif where snow depths are greatest due to redeposition of snow from the summit region. All of these changes can be explained by a continental climate with low summer soil moisture prevailing during the early Holocene 10000 8000 yr BP.

Between 8000 and 4000 yr BP there was a progressive upward movement of elevational limits and pollen abundance maxima for white pine and hemlock. These species are limited to low elevations today. Their expansion to higher elevation suggests a progressive change in a limiting factor, a factor that changes along the elevational gradient. This factor, presumably temperature during the growing season, changed contin- uously until $\approx 4000$ yr BP, reaching a maximum 6000 $4000 \mathrm{yr}$ BP. There was a reversal after that time, but a second factor changed as well, because yellow birch began to increase at many elevations starting $4000 \mathrm{yr}$ $\mathrm{BP}$ and spruce increased $\approx 2000 \mathrm{yr}$ BP.

Gradually summers must have become cooler and winters warmer due to the gradual change in orbital parameters. Superimposed on this change was a change in general circulation that brought warm and moist tropical air masses to northern New England. Warm temperatures resulted, and increased precipitation. Interestingly, hemlock came into the White Mountains before beech, suggesting that it could grow there before conditions were tolerable for beech. Along their western limits today, hemlock extends $200 \mathrm{~km}$ beyond the limit of beech. The western limit of hemlock is apparently determined by moisture, either winter dessiccation or summer drought. However, in the late Holocene, the range of hemlock shifted downslope more rapidly than that of beech. At present its upper elevation limit lies $\approx 100 \mathrm{~m}$ below beech, and the two trees are limited by temperature during the growing season. Cool summers put them at a competitive disadvantage with faster growing hardwoods, such as sugar maple and yellow birch, which are more abundant at higher elevations (Bormann et al. 1970). The sequence suggests that two factors, possibly temperature and moisture, changed coincidentally in the late Holocene, until conditions became similar to the present.

The changes we have observed at lower elevations are not synchronous with tree line changes. The modern boundary between tundra and subalpine fir forest at $\approx 1450 \mathrm{~m}$ is determined by both temperature and wind (Antevs 1932, Daubenmire 1954, Bliss 1963, Harries 1966, Reiners and Lang 1979). Low temperature is the ultimate factor determining tree growth. Daubenmire (1954) has correlated the position of tree line with a mean July temperature of $10^{\circ} \mathrm{C}$. On the southeast slopes of the Presidentials, which are sheltered from wind, patches of krummholz reach $1680 \mathrm{~m}$, where (based on summer lapse rates) the July temperature is $10^{\circ} \mathrm{C}$. Wind is considered by many to be the most important proximate factor in determining the position of tree line in the White Mountains (Monahan 1931, Antevs 1932, Griggs 1942, 1946, Bliss 1963, Harries 1966, Reiners and Lang 1979). Tree line on the windy west slopes of the Presidentials is between 1465 and $1525 \mathrm{~m}$, but it is as low as $1312 \mathrm{~m}$ on exposed northwest slopes. Tree line is higher on east slopes, the lee side of the mountains, usually occurring between 1525 and $1588 \mathrm{~m}$. Tree line is generally higher on the smaller mountains than on the larger Presidential massif.

The fossil record suggests that conditions were initially too cool for forest growth even at low elevations. A change occurred 11500 yr BP, when spruce woodland developed first near Mirror Lake and later at Lost Pond. At that time tree line became established some- 
where between the elevation of Lost Pond $(650 \mathrm{~m})$ and Deer Lake (1490 m) (Spear 1989; Fig. 9). By 10300 yr BP, tree line had passed Deer Lake Bog $(1325 \mathrm{~m})$ and had reached its modern position near Lake of the Clouds $(1542 \mathrm{~m})$. Between 10000 and $5000 \mathrm{yr}$ BP extensive krummholz patches grew above the position of present-day tree line (Spear 1989; Fig. 10).

We believe that the intense summer insolation provided by the Milankovitch orbital changes (Berger 1978) interacted with the climatic effects of the receding ice sheet to produce the changes we have observed in tree line. These included an increase in high-elevation summer temperatures starting $11500 \mathrm{yr} \mathrm{BP}$ and culminating at 9000 yr BP. During this period summer temperatures at tree line changed from much colder than today to conditions warmer than today. By $5000 \mathrm{yr}$ BP temperatures had declined to modern levels (Fig. 10). A change in the direction of prevailing winds from northerly to westerly might also have had an important effect on tree line, but the Lake of the Clouds, where our data were obtained, is exposed to winds from either direction.

The change in lapse rates is evidence that the source region for air reaching the White Mountains changed between the early Holocene and the mid- and late Holocene, presumably because the pattern of general circulation was influenced by the melting of the Pleistocene ice sheet (Kutzbach 1987). Discussions of mountain biogeography frequently reconstruct past distribution of communities, assuming continuity of present-day communities into the past, and shifting them from one elevation to another in parallel. Such a view of the past obviously does not fit the complex history of the White Mountains, and obscures the information that can be obtained about environmental changes revealed by detailed study of vegetation history at all elevations.

Our results emphasize the continual changes in multiple exogenous forces that have affected vegetation in the White Mountains since the area was uncovered by the retreating ice sheet $14000 \mathrm{yr}$ ago. Given the severity of climate prior to $10000 \mathrm{yr}$ ago, and the many independent changes of temperature, seasonality, precipitation, and disturbance that have occurred since, it would be remarkable indeed if plant communities were able to retain the same complement of species over long periods of time.

\section{ACKNOWLEDGMENTS}

Collecting sediment cores from mountain ponds was a difficult task made easier by the help of Jim Ogg, Linda Brubaker, Ann Perters, Isobel Heathcote, Jesse (Mary) Ford, Denise Mitten, Gene Rosenberg, Jan Harlan, and Mike Dahlberg. Jim Ogg, Jan Harlan, and Mike Dahlberg further provided their skills as laboratory technicans preparing and counting pollen and plant macrofossil samples. Dr. R. C. Bright was an invaluable resource for macrofossil identification. Dr. Isobel Heathcote aided in the analysis of surface sample data. Dr. E. J. Cushing generously allowed us to use his computer program POLDATA version 5 to tabulate and plot our results.
Randy Calcote, Jim Leeber-Mack, Ha Lam, Mengistu Fickak, Carrie O'Donoghue-Wolf, Sue Julson, and Bonnie DePuy helped in the preparation of the manuscript. Detailed comments by Dr. S. T. Jackson, an anonymous reviewer, and Dr. G. L. Jacobson (editor) enabled us to vastly improve earlier versions of this manuscript. We greatly appreciate their thoughtful remarks. The project was supported by National Science Foundation Grants DEB 74-02008, 76-24085, and 77-16638 to Margaret B. Davis.

\section{Literature Cited}

Allison, T. D., R. E. Moeller, and M. B. Davis. 1986. Pollen in laminated sediments provides evidence for a mid-Holocene forest pathogen outbreak. Ecology 67:1101-1105.

Anderson, R. S., R. B. Davis, N. G. Miller, and R. Stuckenrath. 1986. History of Late- and Post-Glacial vegetation and disturbance around Upper South Branch Pond, Northern Maine. Canadian Journal of Botany 64:1977-1986.

Antevs, E. 1932. Alpine Zone of Mt. Washington Range. Merril and Webber, Auburn, Maine, USA.

Berger, A. L. 1978. Long-term variations of caloric solar radiation, resulting from the earth's orbital elements. Quaternary Research 15:126-142.

Bernabo, J. C., and T. Webb III. 1977. Changing patterns in the Holocene pollen record from northeastern North America: a mapped summary. Quaternary Research 8:1326.

Bliss, L. C. 1963. Alpine plant communities of the Presidential Range, New Hampshire. Ecology 44:678-697.

Bormann, F. H., T. G. Siccama, G. E. Likens, and R. H. Whittaker. 1970. The Hubbard Brook ecosystems study: composition and dynamics of the tree stratum. Ecological Monographs 40:373-388.

Bormann, R. E., F. H. Bormann, and G. E. Likens. 1985. Catastrophic disturbance and regional landuse. Pages 6572 in G. E. Likens, editor. An ecosystem approach to aquatic ecology: Mirror Lake and its environment. Springer-Verlag, New York, New York, USA.

Bryson, R. A. 1966. Air masses, streamlines, and the boreal forest. Geographical Bulletin 8:228-259.

COHMAP. 1988. Climatic change of the last 18,000 years: observations and model simulations. Science 241:10431052.

Cushing, E. J. 1963. Late-Wisconsinan pollen stratigraphy in east-central Minnesota. Dissertation. University of Minnesota, Minneapolis, Minnesota, USA.

Cwynar, L. C., E. Burden, and J. H. McAndrews. 1979. An inexpensive sieving method for concentrating pollen and spores from fine-grained sediments. Canadian Journal of Earth Science 16:1115-1120.

Daubenmire, R. 1954. Alpine timberlines in the Americas and their interpretation. Butler University Botanical Studies 11:119-136.

Davis, M. B. 1958. Three pollen diagrams from central Massachusetts. American Journal of Science 256:540-570.

- 1965. Phytogeography and palynology of northeastern United States. Pages 377-401 in H. E. Wright and D. G. Frey, editors. The Quaternary of the United States. Princeton University Press, Princeton, New Jersey, USA.

- 1976. Pleistocene biogeography of temperate deciduous forests. Geoscience and Man XIII:13-26.

—. 1981a. Outbreaks of forest pathogens in Quaternary history. Proceedings of the IV International Palynological Conference, Lucknow, India (1976-77) 3:216-228.

- $1981 \mathrm{~b}$. Quaternary history and the stability of forest communities. Pages 132-153 in D. C. West, H. H. Shugart, and D. B. Botkin, editors. Forest succession: concepts and applications. Springer-Verlag, New York, New York, USA.

1983. Quaternary history of deciduous forests of eastern North America and Europe. Annals of the Missouri Botanical Garden 70:550-563. 
1985. History of the vegetation in the Mirror Lake Watershed. Pages 53-64 in G. E. Likens, editor. An ecosystem approach to aquatic ecology: Mirror Lake and its environment. Springer-Verlag, New York, New York, USA.

Davis, M. B., and D. B. Botkin. 1985. Sensitivity of cooltemperate forests and their fossil pollen record to rapid temperature change. Quaternary Research 23:327-340.

Davis, M. B., L. B. Brubaker, and T. Webb III. 1973. Calibration of absolute pollen influx. Pages 9-24 in H. J. B. Birks and R. G. West, editors. Quaternary plant ecology. Blackwell Scientific, Oxford, England.

Davis, M. B., and M. S. (J.) Ford. 1982. Sediment focusing in Mirror Lake, New Hampshire. Limnology and Oceanography 27:137-150.

Davis, M. B., M. S. Ford, and R. E. Moeller. 1985. Paleolimnology: sedimentation. Pages 345-366 in G. E. Likens, editor. An ecosystem approach to aquatic ecology: Mirror Lake and its environment. Springer-Verlag, New York, New York, USA.

Davis, M. B., R. E. Moeller, and M. S. (J.) Ford. 1984. Sediment focusing and pollen influx. Pages 261-293 in E. Y. Haworth and J. W. G. Lund, editors. Lake sediments and environmental history: studies in paleolimnology and paleoecology in honour of Winifred Tutin. University of Leicester Press, Leicester, England.

Davis, M. B., R. W. Spear, and L. C. K. Shane. 1980. Holocene climate of New England. Quaternary Research 14: 240-250.

Davis, M. B., K. D. Woods, S. L. Webb, and R. P. Futyma. 1986. Dispersal versus climate: expansion of Fagus and Tsuga into the Upper Great Lakes region. Vegetatio 67:93103.

Davis, R. B., and R. W. Doyle. 1969. A piston corer for upper sediment in lakes. Limnology and Oceanography 14: 647-648.

Davis, R. B., and G. L. Jacobson, Jr. 1985. Late-glacial and early Holocene landscapes in northern New England and adjacent areas of Canada. Quaternary Research 23:341368.

Davis, R. B., and T. Webb III. 1975. The contemporary distribution of pollen from eastern North America: a comparison with the vegetation. Quaternary Research 5:395434.

Deevey, E. S., Jr. 1943. Additional pollen analyses from southern New England. American Journal of Science 237: 691-724.

-1951. Late-glacial and post-glacial pollen diagrams from Maine. American Journal of Science 249:177-207.

- 1958. Radiocarbon-dated pollen sequences in eastern North America. Zurich, Geobotanical Institute Rubel Veroff 34:30-37.

Delcourt, P. A. 1978. Quaternary vegetational history of the Gulf Coastal Plain. Dissertation. University of Minnesota, Minneapolis, Minnesota, USA.

Dunwiddie, P. W. 1987. Macrofossil and pollen representation of coniferous trees in modern sediments from Washington. Ecology 68:1-11.

Emanuel, K. A. 1987. The dependence of hurricane intensity on climate. Nature 326:483-485.

Faegri, K., and J. Iverson. 1975. Textbook of pollen analysis. Hafner, New York, New York, USA.

Ford, M. S. (J.). 1990. A 10000 -yr history of natural ecosystem acidification. Ecological Monographs 60:57-89.

Garfinkel, H. L., and L. B. Brubaker. 1980. Modern climatetree growth relationships and climatic reconstruction in subArctic Alaska. Nature 286:872-874.

Gaudreau, D. C., S. T. Jackson, and T. Webb III. 1989. Spatial scale and sampling strategy in paleoecological studies of vegetation patterns in mountainous terrain. Acta Botanica Neerlandica 38:369-390.

Gaudreau, D. C., and T. Webb III. 1985. Late-Quaternary pollen stratigraphy and isochrone maps for the northeastern United States. Pages 247-280 in W. M. Bryant and R. G. Holloway, editors. Pollen records of Late-Quaternary North America sediments. American Association of Stratigraphic Palynologists Foundation, Dallas, Texas, USA.

Goldthwait, R. P. 1940. Geology of the Presidential Range. New Hampshire Academy of Science Bulletin 1:5-41.

1970. Mountain glaciers of the Presidential Range in New Hampshire. Arctic and Alpine Research 2:85-102.

- 1976. Past climates on "the hill." Part 1. When glaciers were here. Part 2. Permafrost fluctuations. Mt. Washington Observatory Bulletin (March and June): 12$16,38-41$.

Griggs, R. F. 1942. Indications as to climatic changes from the timberline of Mount Washington. Science 95:515-519. - 1946. The timberlines of northern America and their interpretation. Ecology 27:275-289.

Harries, H. 1966. Soils and vegetation in the alpine and the subalpine belt of the Presidential Range. Dissertation. Rutgers State University, New Brunswick, New Jersey, USA.

Jackson, S. T. 1989. Postglacial vegetational changes along an elevational gradient in the Adirondack Mountains (New York): a study of plant macrofossils. New York State Museum and Science Service Bulletin 465.

Jackson, S. T., and D. R. Whitehead. 1991. Holocene vegetation patterns in the Adirondack Mountains. Ecology 72: 641-653.

Kutzbach, J. E. 1987. Model simulations of the climate patterns during deglaciation of North America. Pages 425446 in W. F. Ruddiman and H. E. Wright Jr., editors. North America and adjacent oceans during the last deglaciation. The geology of North America. Volume K-3. Geological Society of America, Boulder, Colorado, USA.

Kutzbach, J. E., and P. J. Guetter. 1986. The influence of changing orbital parameters and surface boundary conditions on climate simulations for the past 18,000 years. Journal of the Atmospheric Sciences 43:1726-1759.

Leopold, E. B. 1956. Two late-glacial deposits in southern Connecticut. Proceedings of the National Academy of Science (USA) 42:863-867.

Levesque, A. L., F. E. Mayle, I. R. Walker, and L. C. Cwynar. 1993. A previously unrecognized late-glacial cold event in eastern North America. Nature 361:623-626.

Likens, G. E. 1985. Mirror Lake: cultural history. Pages 7283 in G. E. Likens, editor. An ecosystem approach to aquatic ecology: Mirror Lake and its environment. Springer-Verlag, New York, New York, USA.

Likens, G. E., F. H. Bormann, R. S. Pierce, J. S. Eaton, and N. M. Johnson. 1977. Biogeochemistry of a forested ecosystem. Springer-Verlag, New York, New York, USA.

Likens, G. E., and M. B. Davis. 1975. Post-glacial history of Mirror Lake and its watershed in New Hampshire, USA: an initial report. Internationale Vereinigung für theoretische und angewandte Limnologie, Verhandlungen 19:982993.

MacDonald, G. M. 1984. Post-glacial plant migration and vegetation development in the western Canadian boreal forests. Dissertation. University of Toronto, Toronto, Ontario, Canada.

Markgraf, V. 1980. Pollen dispersal in a mountain area. Grana 19:127-146.

Middeldorp, A. A. 1986. Functional paleoecology of the Hahnenmoor raised bog ecosystem: a study of vegetation history, production and decomposition by means of pollen density dating. Review of Paleobotany and Palynology 49: 1-73.

Miller, N. G., and G. G. Thompson. 1979. Boreal and western North American plants in the late Pleistocene of Vermont. Journal of the Arnold Arboretum 60:167-218.

Monahan, R. S. 1931. Timberline study: a general review of influences affecting altitudinal limits of tree growth with 
special reference to their applications on the Presidential Range of the White Mountains, New Hampshire. Thesis. Yale University, New Haven, Connecticut, USA.

Mott, R. J., D. R. Grant, R. Stea, and S. Occhietti. 1986. Late-glacial climate oscillation in Atlantic Canada equivalent to the Allerod/Younger Dryas event. Nature 323:247250.

Oosting, H. J., and W. D. Billings. 1951. A comparison of virgin spruce-fir forest in the northern and southern Appalachian system. Ecology 32:84-103.

Overpeck, J. T., D. Rind, and R. Goldberg. 1990. Climateinduced changes in forest disturbance and vegetation. $\mathrm{Na}$ ture 343:51-53.

Peteet, D. M., J. S. Vogel, D. E. Nelson, J. R. Southon, R. J. Nickmann, and L. E. Heusser. 1990. Younger Dryas climatic reversal in northeastern USA? AMS ages for an old problem. Quaternary Research 33:219-230.

Phleger, F. B. 1955. Ecology of Foraminifera, northwest Gulf of Mexico: Part 1. Foraminifera distribution. Geological Society of America Memoir 46:1-88.

Prentice, I. C. 1986. Vegetations response to past climatic variation. Vegetatio 67:131-141.

Prentice, I. C., P. J. Bartlein, and T. Webb III. 1991. Vegetation and climate change in eastern North America since the last glacial maximum. Ecology 72:2038-2056.

Reiners, W. A., and G. E. Lang. 1979. Vegetational patterns and processes in the balsam fir zones, White Mountains, New Hampshire. Ecology 60:403-417.

Rind, D., D. Peteet, W. Broecker, A. McIntyre, and W. Ruddiman. 1986. The impact of cold North Atlantic sea surface temperatures on climate: implications for the Younger Dryas cooling (11-10k). Climate Dynamics 1:3-33.

Shane, L. C. K. 1987. Late-glacial vegetational and climatic history of the Allegheny Plateau and the till plains of Ohio and Indiana, U.S.A. Boreas 16:1-20.

Solomon, A. M., and A. B. Silkworth. 1986. Spatial patterns of atmospheric pollen transport in a montane region. Quaternary Research 25:150-162.

Spear, R. W. 1981. The history of high-elevation vegetation in the White Mountains of New Hampshire. Dissertation. University of Minnesota, Minneapolis, Minnesota, USA. . 1989. Late-Quaternary history of high-elevation in the White Mountains of New Hampshire. Ecological Monographs 59:125-151.

Sprugel, D. G. 1976. Dynamic structure of wave-regenerated Abies balsamea forests in the northeastern United States. Journal of Ecology 64:889-905.

Sprugel, D. G., and F. H. Bormann. 1981. Natural disturbance and the steady state in high-altitude balsam fir forests. Science 211:390-393.

Stockmarr, J. 1971. Tablets with spores used in absolute pollen analysis. Pollen et Spores 13:615-621.

Watts, W. A. 1979. Late Quaternary vegetation of central Appalachia and the New Jersey coastal plain. Ecological Monographs 49:427-469.

Webb, T., III. 1986. Vegetational change in eastern North America from 18,000 to 500 yr BP. Pages 63-69 in C. Rosenweig and R. Dickinson, editors. Climate-vegetation interactions. Office for Interdisciplinary Earth Studies, University Corporation for Atmospheric Research, Boulder, Colorado, USA.

Webb, T., III, P. J. Bartlein, and J. E. Kutzbach. 1987. Climatic change in eastern North America during the past 18,000 years: comparisons of pollen data with model re. sults. Pages 447-461 in W. F. Ruddiman and H. E. Wright, Jr., editors. North America and adjacent oceans during the last deglaciation. The geology of North America. Volume K-3. Geological Society of America, Boulder, Colorado, USA.

Webb, T., III, P. J. H. Richard, and R. J. Mott. 1983. A mapped history of Holocene vegetation in southern Quebec. Syllogeus 49:273-336.

Webster, P. J., and N. A. Streten. 1978. Late Quaternary Ice Age climate of tropical Australia: interpretations and reconstructions. Quaternary Research 10:279-309.

Wright, H. E., Jr. 1989. The amphi-Atlantic distribution of the Younger Dryas paleoclimatic oscillation. Quaternary Science Reviews 8:295-306.

Wright, H. E., E. J. Cushing, and D. A. Livingstone. 1965. Coring devices for lake sediments. Pages 494-520 in B. Kummel and D. M. Raup, editors. Handbook of paleontological techniques. Freeman, San Francisco, California, USA. 